\title{
International Law in the Colombian Transition
}

Colombia has assigned a central role to international law in its transition from armed conflict to peace. Even though this question became more visible since the recent peace process and the 2016 Peace Agreement concluded in the country, international law has been present in all the previous transitional mechanisms that Colombia has adopted since 2005. Colombia has a legal system widely receptive to international law, with a Constitution attributing to IHRL and IHL treaties duly ratified by the country the same normative level as the constitutional order. ${ }^{1}$ This feature has been particularly relevant regarding the political and legal discussions on armed conflict and transition to peace in the country.

As such, this chapter examines how international law is reflected in transition in Colombia. The focus is given to the 2012-2016 peace process and the 2016 Final Agreement, but the analysis also incorporates elements from the previous transitional mechanisms designed in the country. The purpose of the chapter is to show how international law has shaped transition in Colombia, seeking empirical elements to assess how this case can be framed under jus post bellum. For that, Chapter 3 will overlap the conceptual framework offered in Chapter 1 with the practice exposed in this Chapter 2, to suggest how jus post bellum can be understood and applied from the perspective of the case study.

The chapter departs from offering a general overview of the Colombian armed conflict and its transition to peace. Such a background is important to better understand the complexities of this conflict, its root causes and dynamics, the different attempts to reach peace, and the challenges to implement an ambitious peace deal while armed conflict still persists in the country. Then, the chapter analyzes the main aspects in which international law has shaped the Colombian transition: the legal nature of the peace agreement, socioeconomic and political reforms, criminal justice, reparations, and inclusiveness. In each component, the chapter identifies the international legal framework relevant to the respective matter-including legal norms, legal discourses, and legal practices-, and then it analyzes how such a framework was applied in Colombia. On this point, it is important to clarify that even if the Colombian transition has involved several matters relevant to jus post bellum, the selection

1 Constitución Política de Colombia, 1991, Art. 93. 
of topics in this chapter is focused on the components in which the influence of international law is more specific and visible.

\section{A General Overview of the Colombian Armed Conflict and Its Transition to Peace}

This section summarizes the general elements to understand the origin, actors, and evolution of the Colombian armed conflict, as well as the main instruments and processes aimed at reaching peace in the country.

\subsection{Origin and Evolution of the Armed Conflict}

Since its independence and the configuration of the Republic in 1819, Colombia was politically divided into two traditional parties: liberals and conservatives. Both parties fought for power in different ways, leading to an intensive violent period known as The Thousand Days War (1899-1902). ${ }^{2}$ Peace was agreed upon, but violence reappeared after several hegemonic conservative governments. In 1948 the presidential candidate by the Liberal Party was assassinated, which triggered a new civil war known as La Violencia. It lasted until 1958. That year, a settlement was reached between the Liberal and the Conservative Party, in which they agreed to alternate power for 16 years. ${ }^{3}$

Beyond those agreements among the two traditional parties, many people-mostly peasants and social leaders_-did not feel represented by such a political system. Thus, some peasants organized movements demanding land access and rural development programs. Those demands were ignored by the government, who saw them as a communist threat in the global context of the Cold War. Repressive measures were the response, and organized peasants, together with communist militants, founded the left-wing guerrilla Fuerzas Armadas Revolucionarias de Colombia (FARC) in 1964, and later the Ejército de Liberación Nacional (ELN) the same year. Both groups-though different ideological approaches_claimed the use of arms to defend themselves from governmental repression and seek social justice under a communist thought.

The two guerrillas gained rapid expansion across the country, and other small guerilla groups appeared in the following two decades, owing a combination

2 See generally, Marco Palacios, Entre la legitimidad y la violencia: Colombia 1875-1994, (Bogota: Banco de la Republica, 1995).

3 See generally: Daniel Pécaut, Crónica de cuatro décadas de política colombiana, (Bogota: Norma, 2006). 
of popular support and unsuccessful governmental strategies to reach a solution. In that scenario, in the early 1980s, some landowners organized themselves in a self-defense strategy against the guerrillas, which had used extortion and kidnaping as their main source of income. That process led to the conformation of paramilitary groups, gathered under the Autodefensas Unidas de Colombia (AUC) in the 199os. ${ }^{4}$ They received illegal support by different state agents, which intensified the armed confrontation around the country. Simultaneously, Colombia was experiencing an unprecedented growth in drug production and trafficking, which carried out alliances between traffickers and armed groups, adding new complexities to the armed conflict.

In 1991 a new Constitution was adopted, following peace negotiations with small guerrilla groups which appeared during the $1970 \mathrm{os}$ and 1980s. It opened democracy and gave people better mechanisms to protect their rights. However, in the mid-199os, the lucrative traffic of illegal drugs and the struggle over territorial control intensified armed confrontation between the FARC and the ELN by one side, and the State and the paramilitary groups by the other. Several war crimes and crimes against humanity were committed by all actors, and Colombia entered the path of a failed state. ${ }^{5}$

A hope of peace appeared in 1998. A peace process with the FARC started, but four years later it failed after the guerrilla committed several abuses during the negotiations. In 2002 a new government initiated the most intensive military offensive against the guerrilla. At the time, a process for the demobilization of the paramilitary groups was implemented between 2003 and 2005, under a scheme of submission to the State in exchange for socioeconomic and legal benefits. It brought a significant decrease in the armed confrontation.

However, after ten years of military offensive, the guerrillas were reduced but not defeated. In 2012 a new peace process started with the FARC, still the largest and oldest armed group in Colombia. ${ }^{6}$ After four years of negotiations,

4 See generally Centro Nacional de Memoria Histórica, Paramilitarismo. Balance de la Contribución del CNMH al Esclarecimiento Histórico, (Bogotá, Centro Nacional de Memoria Histórica, 2018).

5 Gregoy Lobo, "Colombia, from Failing State to a Second Independence: The Politics and the Price”, International Journal of Cultural Studies 16, no. 4 (2012): 351-366.

6 Gobierno de Colombia and farc, 'Acuerdo General Para La Terminación Del Conflicto y La Construcción de Una Paz Estable y Duradera,' 26 August 2012, http://www.altocomisionadoparalapaz.gov.co/procesos-y-conversaciones/acuerdo-general/Paginas/inicio.aspx (accessed on 5 March 2016). 
a Final Peace Agreement was reached in 2016. Nevertheless, the other guerrilla group, the ELN, remains active, with low military capacity and several unsuccessful negotiations attempts. ${ }^{7}$

More than five decades of armed conflict have left millions of victims in Colombia. In 2011 the Unified Victim's Registry was created. ${ }^{8}$ This tool registers victims who suffered any damage during the armed conflict since the 1st January 1985. Up to April 2019, 8.803.836 victims are registered, ${ }^{9}$ which represents the $18 \%$ of the current Colombian population. ${ }^{10}$ Most victims were affected by internal displacement (7.478.723), followed by homicide (269.650) and enforced disappearance $(47 \cdot 560) .{ }^{11}$

\subsection{Transitional Legal Mechanisms in the Ongoing Conflict}

During its protracted armed conflict, Colombia has developed several legal and constitutional instruments to protect and redress victims, to facilitate peace negotiations, and to reintegrate members of armed groups into civilian life. In 1997 a legal framework was adopted for assisting victims of internal displacement. ${ }^{12}$ It was later complemented by the jurisprudence of the Constitutional Court, ${ }^{13}$ offering not only humanitarian and socio-economic assistance but seeking also reparations and durable solutions. In 2005 the Justice and Peace Law $^{14}$ created a system of transitional justice for the demobilization of paramilitary groups, in talks with the government since 2003. The system was framed within the ordinary Colombian jurisdiction, offering to former fighters a trial with alternative punishment ( $5^{-8}$ years in prison) in exchange for their contribution to peace.

Julia Zulver, ¿Verá Colombia un acuerdo de paz con el ELN en 2019?, Open Democracy, 7 January 2019, https://www.opendemocracy.net/es/democraciaabierta-es/ver-colombiaun-acuerdo-de-paz-con-el-eln-/ (accessed on 10 April 2019). Congreso de la República de Colombia, Ley 1448 (Ley de Víctimas y Restitución de Tierras) Art. 154.

9 Registro Único de Víctimas, https://www.unidadvictimas.gov.co/es/registro-unico-devictimas-ruv/37394 (accessed on 1 April 2019).

10 The total population of Colombia up to May 2019 is estimated in 48.2 million people. Source: http://www.dane.gov.co/index.php/estadisticas-por-tema/demografia-y-poblacion/ censo-nacional-de-poblacion-y-vivenda-2018/cuantos-somos/ (accessed on 5 May 2019).

11 Registro Único de Víctimas, https:/www.unidadvictimas.gov.co/es/registro-unico-devictimas-ruv/37394 (accessed on 1 April 2019).

12 Congreso de la República de Colombia, 'Ley 387' (1997).

13 Corte Constitucional de Colombia, Sentencia T-025/04 (2004).

14 Congreso de la República de Colombia, 'Ley 975 (Ley de Justicia y Paz)' (2005). 
Finally, and despite the ongoing armed conflict, in 2011 Colombia adopted the Law $1448,{ }^{15}$ known as Law of Victims and Land Restitution. Following international standards on reparation, this law set up an ambitious system to register all the victims of armed conflict since 1985 and to offer a comprehensive set of measures of restitution, compensation, rehabilitation, satisfaction, and guarantees of non-repetition.

\subsection{Peace Process and Final Agreement (2012-2016)}

The recent peace process with the FARC represents the most important attempt to achieve peace in Colombia. It advanced a negotiation scheme aimed not only at ending the armed conflict but also to address its root causes. After four years of negotiations ${ }^{16}$ in Havana, Cuba, the parties signed a final agreement on 26 August 2016, which was later rejected in a plebiscite. ${ }^{17}$ After a renegotiation following the requests of the main opposing leaders, a new agreement was reached on 24 November 2016, which was then approved by the Colombian Congress. ${ }^{18}$

The Agreement addresses six issues: 1) Rural development, improving land access and the productive capacities of peasants; 2) Political participation, expanding the democratic spectrum to new actors, including the former guerrilla; 3) End of the conflict, involving the laying down of arms and reintegration issues; 4) Solution to the problem of illicit drugs, as one of the fuels of the conflict; 5) Victims and transitional justice, establishing a comprehensive system of justice, truth, and reparation; and 6) An implementation and verification system with international support.

\section{The Legal Status of the Peace Agreement}

Since peace negotiations and peace agreements have become a highly "normatized" process, ${ }^{19}$ determining the legal status of the resulting deal has been a

\footnotetext{
15 Congreso de la República de Colombia, Ley 1448 (Ley de Víctimas y Restitución de Tierras).

16 Although the process took four years, the peace negotiations in Colombia are considered the fastest moving peace talks in the world. Escola de Cultura de Pau, Yearbook of Peace Processes 2015, ed. Vicenç Fisas (Barcelona: Icaria, 2015), 9.

17 ввс News, Colombia referendum: Voters reject Farc peace deal, 3 October 2016, https:// www.bbc.com/news/world-latin-america-37537252 (accessed on 10 April 2019).

18 Government of Colombia and FARC, 'Final Agreement to End the Armed Conflict and Build a Stable and Lasting Peace.'

19 Kastner, Legal Normativity in the Resolution of Internal Armed Conflict, 2.
} 
matter of utmost importance. If the agreement is not seen as legally binding, the parties' confidence can be affected to the point that reaching an accord becomes difficult. This question is especially relevant in negotiations following NIAC s. In such negotiations, the non-state actors are invariably concerned that the government will use its law-making powers to modify its commitments during the implementation phase.

In the Colombian case, such a concern was held by both the government and the FARC. Even if the government was committed to the implementation of the agreement during negotiation, there was a risk that a new government, the Congress or the Constitutional Court could modify what was agreed upon.

As such, the discussion on the legal nature of the peace agreement in Colombia was almost as central to the negotiation as those focused on substantial issues. The debate progressed from the intention to promote a new constitution integrating the peace deal to the idea of forming the agreement as an international legal document. The first option was rejected by the government, which insisted on adopting a deal under the existing constitutional framework. The FARC accepted such a position but remained apprehensive about the legal nature of the agreement. Subsequently, the idea of lending some form of international legal character to the accord prevailed as a means to guarantee that the State would not be able to amend it under domestic law.

In a joint communiqué issued on 12 May 2016, the parties announced a formula to grant legal certainty to the Final Agreement and guarantee compliance to it under both domestic and international law. The formula included two elements rooted in international law. First, declaring the Final Agreement as a special agreement in terms of Common Article 3 of the Geneva Conventions. Second, the formula involved a unilateral declaration by the Colombian State before the UN requesting that the Final Agreement be annexed to the UNSC Resolution 2261 (2016), which established a monitoring mission for the implementation of the peace agreement in Colombia.

Having said elements, this section is divided into three parts. The first part will focus on the discussion of the domestic or international legal status of internal peace agreements. The second part will present the two mechanisms agreed upon in Colombia to lend the peace agreement international legal value. The third part will analyze the potential effects of the use of international law to enhance the legal certainty of the peace deal in Colombia. 


\subsection{The Discussion on the Domestic or International Legal Status of Internal Peace Agreements}

The legal-looking ${ }^{20}$ structure and language used in peace agreements show the parties' intention to consider them as legally binding documents. ${ }^{21}$ However, as a rule, these agreements are political documents that must be translated into a legal form for their implementation. ${ }^{22}$ Nevertheless, internal peace agreements "do not easily fit within traditional international or domestic legal categories," because they entail a mix of state and non-state actors, and a combination of matters belonging to national and international spheres. ${ }^{23}$

In the case of agreements following NIACs, their legal status is typically given by domestic law in the form of a new constitution ${ }^{24}$ or through constitutional amendments or new laws. ${ }^{25}$ However, as Kastner highlights,

Peace agreements can be understood as hybrid instruments between a state and nonstate actors to deal with a domestic situation, but which are often internationalized through references to international law. Such internationalization brings the agreement into the sphere of international legal norms and arguably confers additional legitimacy. ${ }^{26}$

20 Peace agreements are not legal documents in their own but their writing normally has a legal style.

21 Bell, 'Peace Agreements: Their Nature and Legal Status,' 378.

22 Colin Harvey, 'On Law, Politics and Contemporary Constitutionalism,' Fordham International Law Journal 26, no. 4 (2002): 999. Regarding the Colombian Peace Agreement, the Constitutional Court considered it as a mere political document (Sentence C-379/ 2016). Even the Court refrained from deciding a constitutionality action concerning the Peace Agreement, arguing that such a document does not have any normative, but only political character. Sentence C-171/2017.

23 Arist von Hehn, The Internal Implementation of Peace Agreements after Violent Intrastate Conflict (Leiden: Martinus Nijhoff, 2011), 50-51.

24 For example, South Africa, where the 1993 accord was written to serve as an "interim constitution" until the accord could be legally ratified as part of a final constitution. Peace Accords Matrix, https://peaceaccords.nd.edu/provision/ratification-mechanisminterim-constitution-accord, Kroc Institute for International Peace Studies, University of Notre Dame.

25 For example, the Northern Ireland Good Friday Agreement, in which it as agreed that if majorities were reached in the referendums on the agreement, "the Governments will then introduce and support, in their respective Parliaments, such legislation as may be necessary to give effect to all aspects of this agreement." Peace Accords Matrix, https:// peaceaccords.nd.edu/provision/ratification-mechanism-northern-ireland-good-fridayagreement, Kroc Institute for International Peace Studies, University of Notre Dame.

26 Kastner, Legal Normativity in the Resolution of Internal Armed Conflict, 13. 
In legal terms, this internationalization of internal peace agreements aims to protect the agreements from substantial variations during the domestic process of translating them into constitutional or legal forms. Indeed, when discussing the legal norms to implementing a deal, opposition groups could press the government or other actors to backtrack on commitments. To address these difficulties, Bell suggests that peace agreements "tend to include substantive reform of legislative and constitutional processes and institutions that make international law a key reference point and give international actors a role in what are normally domestic institutions." ${ }^{27}$ However, it is not clear if such internationalization make an internal peace agreement to become an international legal instrument.

Article 2.1(a) of the 1969 Vienna Convention on the Law of Treaties (VCLT) defines a treaty as "an international agreement concluded between States in written form and governed by international law."28 In this line, Article 2.1(a) of the 1986 Vienna Convention on the Law of Treaties between States and International Organizations or between International Organizations ${ }^{29}$ extends the same definition to agreements concluded between states and international organizations or among these organizations. In these terms, agreements reached between a state and a non-state actor are not considered treaties.

However, Article 3 of both conventions specifies that the fact that they do not apply to agreements outside of the definition provided by Article 2.1 does not affect the legal value of those agreements. In particular, Article 3 of the 1986 Convention states that the fact that it does not apply "(i) to international agreements to which one or more States, one or more international organizations and one or more subjects of international law other than States or organizations are parties; [...] shall not affect: (a) the legal force of such agreements; (b) the application to them of any of the rules set forth in the present Convention to which they would be subject under international law independently of the Convention." (emphasis added). ${ }^{30}$

In consequence, both conventions make clear that in addition to treaties, other international agreements can exist. Given this, and considering that

27 Bell, 'Peace Agreements: Their Nature and Legal Status,' 405.

28 Vienna Convention on the Law of Treaties (1969).

29 Vienna Convention on the Law of Treaties between States and International Organizations or between International Organizations (1986). This Convention is not yet into force, as it has not reached the minimum of 35 state's ratifications established to this effect by its Article 85.

30 Vienna Convention on the Law of Treaties between States and International Organizations or between International Organizations (1986). 
there is no legal definition for an international agreement other than a treaty, a systematic reading of both conventions could offer a solution. The conventional definitions of a treaty have three elements in common: first, the parties possess international legal subjectivity; second, the agreement should be governed by international law; and third, the agreement has a written form. This last condition is a formal one, and it does not entail major analytical challenges. However, the other two are substantial, and they could determine whether an agreement should be considered an international one even if it is beyond the scope of the Vienna Conventions.

By this logic, an agreement concluded between a state and a non-state armed group — as is the case with a peace agreement ending a NIAC - could be considered an international agreement, even though it is outside the scope of the Vienna Conventions on the Law of Treaties. ${ }^{31}$ The two substantial conditions discussed above would be present in an internal peace agreement. On the first condition, as pointed out by Bell, in relation to peace agreements signed by armed opposition groups, those groups "can be argued to be 'subjects of international law' - based on international law's recognition of such groups, in particular through humanitarian law."32 On the second condition, Common Article 3 to the 1949 Geneva Conventions allows the conclusion of special agreements with or between non-state armed groups in a NIAC, which will be governed by that international regime.

An analysis of these two elements in an internal peace agreement can be found in a 2004 decision of the Special Court for Sierra Leone, in which the Court denied the international legal nature of the 1999 Lomé Peace Agreement. On the one hand, the Court affirmed that even if "there is now no doubt that [Common Article 3 to the Geneva Conventions] is binding on States and insurgents alike and that insurgents are subject to international humanitarian law [...] [t]hat fact, however, does not by itself invest [a non-state armed group] with international personality under international law."33 On the other hand, the Court stated that even though the Lomé Agreement put an end to an armed conflict and was welcomed by the international community acting

31 Bell, On the Law of Peace, 129; Laura Betancur, 'The Legal Status of the Colombian Peace Agreement,' American Journal of International Law 110 AJIL Unbound Symposium on the Colombian Peace Talks and International Law (2016): 189 .

32 Bell, On the Law of Peace, 130. This subjectivity is generally recognized, despite the fact that governments have always tried to exclude non-state armed groups from international law. See generally, Andrew Clapham, 'Non-State Actors,' in Post-Conflict Peacebuilding: A Lexicon, ed. Vincent Chetail (Oxford: Oxford University Press, 2009), 201.

33 Special Court for Sierra Leone, The Appeals Chamber, Prosecutor v. Morris Kallon and Brima Bazzy Kamara (13 March 2004). para. 45. 
through the UNSC, the agreement itself "created neither rights nor obligations capable of being regulated by international law." 34

Nevertheless, in contrast to the position held by the Court, a different conclusion could be deducted from an analysis of the matter under IHL. Regarding the legal capacity of non-state armed actors to subscribe to international agreements, Bell points out that international legal subjectivity is different from international legal personality. ${ }^{35}$ While the latter implies full capacity to exercise rights and obligations at an international level, the notion of legal subjectivity is limited. In this regard, as long as IHL recognizes the rights and duties of non-state armed groups, they enjoy international legal subjectivity under this regime. At the same time, as analyzed in the next part of this section, special agreements concluded by the parties in a NIAC under Common Article 3 of Geneva Conventions are indeed governed by IHL.

Therefore, a peace agreement ending a NIAC could potentially be considered an international legal accord and as such governed by international law. This question will be analyzed based on the Colombian case.

\subsection{Formulas of Normative Internationalization of the Colombian Peace Agreement}

As previously noted, even before a final agreement was reached, parties in Colombia defined two formulas aimed at giving international legal value to the resulting peace agreement: one, considering the Agreement as a special agreement under IHL; the other, making a unilateral declaration by the State expressing its international commitment to comply the peace deal. This item analyzes each of them.

1.2.1 The Peace Agreement as a Special Agreement under IHL

The first and most important mechanism used by the parties to give international legal status to the Peace Agreement in Colombia was to subscribe it as a special agreement under Common Article 3 of the Geneva Conventions. To do so, the parties agreed, even before the final deal was reached, ${ }^{36}$ in a formula

34 Special Court for Sierra Leone, The Appeals Chamber, paragraph 42. para. 42. In a critic to this decision, Cassese points out that there was no need for the Court to discuss the domestic or international legal status of the agreement, but just to analyze the case regarding the prohibition on amnesties for international crimes. See Antonio Cassese, 'The Special Court and International Law The Decision Concerning the Lomé Agreement Amnesty,' Journal of International Criminal Justice 2, no. 4 (2004): 1130-40.

35 Bell, On the Law of Peace, 135.

36 Gobierno de Colombia and FARC, 'Comunicado Conjunto No. 69.' 
that the Congress translated into a transitory article in the Constitution to qualify the Final Peace Agreement as a "Special Agreement in terms of Common Article 3 of the Geneva Conventions." ${ }^{37}$ In addition, the amendment stated that once signed and entered into force, the Final Agreement would be part of the "constitutional block." 38

This formula has important consequences under Colombian constitutional law. According to article 93 of the National Constitution, IHRL and IHL instruments duly ratified by Colombia prevail in the domestic order. This norm has been interpreted by the Constitutional Court as meaning that those norms have the same normative level as the Constitution itself and, in this way, form a constitutional block. ${ }^{39}$ With this understanding, the constitutional amendment made explicit that the Final Agreement would have the same internal legal status as IHRL and IHL treaties.

This constitutional provision was strongly criticized by some sectors in Colombia through two main arguments. Critics argued that the IHL's mechanism of special agreements is reserved for strictly humanitarian issues and cannot be invoked for a document referring to various economic, political, and social matters. Other critics argued that a peace agreement cannot have the same internal legal status that the Constitution devotes to international human rights and IHL treaties.

Disregarding those critics, the parties subscribed the agreement signed on 24 August 2016 in the terms referred to above. However, after the agreement was rejected by a plebiscite a few weeks later, a renegotiation process took place, during which the opposing actors asked for a modification on this point.

The new Final Agreement reached on 24 November 2016 retained the formula of the special agreement in terms of Common Article 3 of the 1949 Geneva Conventions but added that it would be "to the effects of its international validity."40 In this line, a copy of the Agreement was sent to the Swiss Federal Council as depositary of the Geneva Conventions. ${ }^{41}$

Because of this limitation on the scope of the formula of the Special Agreement, a new constitutional amendment was adopted to substitute the

37 Congreso de la República de Colombia, Acto Legislativo oı de 2016.

38 Ibid.

39 Corte Constitucional de Colombia, Sentencia C-574 de 1992.

40 The parties stated in the Preamble of the Agreement that it was subscribed "as a Special Agreement pursuant to Article 3, common to the 1949 Geneva Conventions, as per its international standing." Government of Colombia and FARC, 'Final Agreement to End the Armed Conflict and Build a Stable and Lasting Peace,' 5 . 
previous one. This time, the reform introduced a transitory article to the Constitution stating that the contents of the Final Agreement "related to norms of international humanitarian law and fundamental rights [...] will be compulsory parameters of interpretation and a referent for the development and validity of the norms and laws developing and implementing the Final Agreement." ${ }^{2}$ Additionally, it established that all the organs of the State must act according to what was agreed on, "preserving the contents, commitments, the spirit, and the principles of the Final Agreement." 43

This new formula has two dimensions. For international effects, the parties considered the Final Agreement a special agreement under IHL. Domestically, the Final Agreement is no longer considered to have the same constitutional effect of IHRL and IHL treaties, but the elements related to IHL and fundamental rights are considered a parameter for the validity of the normative development of the Agreement.

To analyze this question, it is important to note that the mechanism of special agreements is enshrined by Common Article 3 to 1949 Geneva Conventions and applicable to NIACs. The final part of this Article is worded as follows: "The Parties to the conflict should further endeavour to bring into force, by means of special agreements, all or part of the other provisions of the present Convention. The application of the preceding provisions shall not affect the legal status of the Parties to the conflict."

This norm was conceived when NIAC s were uncommon and unregulated by international law. Thus, in principle, special agreements were aimed at spreading the application of Geneva Conventions to NIACs beyond the minimum regulation of Common Article 3. In this sense, the $195^{2}$ ICRC Commentary on Geneva Convention I stated that "Although the only provisions which the individual Parties are bound to apply unilaterally are those contained in Article 3, they are nevertheless under an obligation to try to bring about a fuller application of the Convention by means of a bilateral agreement." 44

Nevertheless, in the Colombian context the mechanism of special agreements "was used with a much broader objective: to increase legal certainty for the parties by reinforcing the deal's domestic and international effects." ${ }^{\prime 5}$ Such a use of the mechanism by the parties in Colombia raises two questions. First,

42 Congreso de la República de Colombia, Acto Legislativo o2 de 2017. Available at: http:// es.presidencia.gov.co/normativa/normativa/ACTO\%2OLEGISLATIVO $\% 20 N^{\circ} \% 2002 \% 20$ DE\%2011\%20DE\%2oMAYO\%2oDE\%2O2017.pdf

43 Ibid.

44 ICrC, Commentary I Geneva Convention, (Geneva, 1952), 59.

45 Betancur, 'The Legal Status of the Colombian Peace Agreement,' 188. 
what is the international normative character of special agreements? Second, can peace agreements be considered special agreements in terms of Common Article 3?

In 1995, assessing the constitutionality of Additional Protocol II as adopted by Colombia, the Constitutional Court referred to Common Article 3's mechanism of special agreements. The Court stated that those agreements are not, stricto sensu, treaties, as they are not established between subjects of public international law. However, the Court admitted that they are a valid legal mechanism to protect the victims of war, to foster consensus and increase reciprocal trust among the enemies for the pursuit of peace. ${ }^{46}$

On this point, as discussed above, special agreements are not treaties in terms of the 1969 and 1986 Vienna Conventions on the Law of Treaties. Since special agreements are formed between parties in a NIAC, at least one of those parties lacks the legal capacity to subscribe to treaties. Nevertheless, as discussed above, there are international agreements other than treaties, as long as they are subscribed by subjects of international law and susceptible to being regulated by this law. It is at this point where special agreements have international legal value.

As previously stated, non-state armed groups are subjects of IHL, a regime under which they are not only bound to respecting existing humanitarian rules but also allowed to create new ones through special agreements. In other words, non-state actors have a norm-creating power with respect to IHL, ${ }^{47}$ though this fact does not give them any specific legal status. ${ }^{48}$

Additionally, as pointed out by Vierucci, since the notion and the content of special agreements are given by treaties of an international character (e.g., Geneva Conventions), the obligations they stipulate should also be regarded as international. ${ }^{49}$ Thus it can be concluded that as long as special agreements create mutual obligations for the parties in a NIAC in terms of Common Article 3 and are binding for the parties under Geneva Conventions, these Agreements

46 Corte Constitucional de Colombia. Sentencia C-225/95 (18 May 1995), para. 17.

47 Anthea Roberts and Sandesh Sivakumaran, 'Lawmaking by Nonstate Actors: Engaging Armed Groups in the Creation of International Humanitarian Law, Yale Journal of International Law 13, no. 1 (2012): 108.

48 Sandesh Sivakumaran, 'The Addressees of Common Article 3,' in The 1949 Geneva Conventions. A Commentary, ed. Andrew Clapham, Paola Gaeta, and Marco Sassòli (Oxford: Oxford University Press, 2015), 426.

49 Luisa Vierucci, 'Applicability of the Conventions by Means of Ad Hoc Agreements,' in The 1949 Geneva Conventions. A Commentary, ed. Andrew Clapham, Paola Gaeta, and Marco Sassòli (Oxford: Oxford University Press, 2015), 516. 
should therefore have the same international legal value as the rest of their IHL obligations.

In this sense, special agreements face the same challenges related to enforceability as other IHL norms. On this topic, Heffes and Kotlik consider that as long as the parties assign greater legitimacy to the obligations created by themselves acting under international law, there are better "chances of voluntary compliance in the first place," at the time that the parties can create their own ad hoc enforceability mechanisms in the agreement. ${ }^{50}$ Vierucci endorses this idea. However, she also mentions enforcement mechanisms through individual criminal responsibility (since the deal becomes a rule of IHL that could be considered a standard by a national or international court ruling over a war crime) $)^{51}$ and state responsibility (since the special agreement creates international obligations for the state). ${ }^{52}$

Likewise, in discussing whether a peace agreement can be considered a special agreement, the answer is affirmative among the ICRC and the few scholars that have seized the matter. For Heffes and Kotlik, "ceasefire agreements and peace agreements could also be included within this category inasmuch as they bring into force humanitarian provisions, since they are concluded by the parties to the conflict." ${ }^{23}$ Heffes and Kotlik support this idea based on the fact that many peace agreements include humanitarian provisions such as the return of displaced people, the location of landmines, the search of disappeared people, and other measures responding to the purpose of special agreements.

Along the same lines, in its 2016 Commentary on Geneva Convention I, the ICRC proposed a broad understanding of the content and form of special agreements as enshrined by Common Article 3. In such a case, there would be no need to name the agreement as a special agreement. For the ICRC, "What counts is that the provisions brought into force between the Parties serve to protect the victims of armed conflict.".54 On this point, the ICRC specifically stated that:

50 Ezequiel Heffes and Marcos Kotlik, 'Special Agreements as a Means of Enhancing Compliance with IHL in Non-International Armed Conflicts: An Inquiry into the Governing Legal Regime,' International Review of the Red Cross 96, no. 895/896 (2014): 1222. See also Liesbeth Zegveld, Accountability of Armed Opposition Groups in International Law (Cambridge: Cambridge University Press, 2002), 28-30; Andrew Clapham, Human Rights Obligations of Non-State Actors (Oxford: Oxford University Press, 2006), 297. They note how special agreements create legally binding obligations for state and non-state actors that could give rise to individual international criminal responsibility.

$5^{2}$ Vierucci, 'Applicability of the Conventions by Means of Ad Hoc Agreements,' 518-20.

53 Heffes and Kotlik, 'Special Agreements as a Means of Enhancing Compliance with IHL in Non-International Armed Conflicts: An Inquiry into the Governing Legal Regime,' 1197. ICRC, Commentary on the First Geneva Convention, 2nd ed. (Geneva, 2016), para. 847. 
A peace agreement, ceasefire or other accord may also constitute a special agreement for the purposes of common Article 3, or a means to implement common Article 3, if it contains clauses that bring into existence further obligations drawn from the Geneva Conventions and/ or their Additional Protocols. In this respect, it should be recalled that 'peace agreements' concluded with a view to bringing an end to hostilities may contain provisions drawn from other humanitarian law treaties, such as the granting of an amnesty for fighters who have carried out their operations in accordance with the laws and customs of war, the release of all captured persons, or a commitment to search for the missing. If they contain provisions drawn from humanitarian law, or if they implement humanitarian law obligations already incumbent on the Parties, such agreements, or the relevant provisions as the case may be, may constitute special agreements under common Article 3. This is particularly important given that hostilities do not always come to an end with the conclusion of a peace agreement. ${ }^{55}$

According to these terms, the ICRC explicitly recognizes a broad scope to special agreements that can also include peace agreements. Even if the Colombian Peace Agreement is the first one in which the parties expressly claimed it to be regarded as a special agreement under Common Article 3, the ICRC has considered other peace deals to have the same character. ${ }^{56}$ In these cases, the defining element of a special agreement is its inclusion of provisions governed by IHL, as in the case of amnesties and the search of missing people, for example. Based on this criterion, the Final Peace Agreement concluded by the Colombian government and the FARC in 2016 can be indeed considered a special agreement in terms of Common Article 3 to 1949 Geneva Conventions.

\subsubsection{The Peace Agreement as a Document of the UN Security Council}

The second mechanism aimed at giving international legal character to the Colombian Peace Agreement was its incorporation into a UNSC resolution. The parties agreed that the President of the Republic would make a unilateral declaration before the UN Secretary-General to request him to welcome

55 ICRC, Commentary on the First Geneva Convention, 2nd edition, 2016, para. 850.

56 The ICRC mentions here the Cotonou Agreement on Liberia (1993), ICRC, Commentary on the First Geneva Convention, n. 803. Heffes and Kotlick also include the example of the 2002 Cease Fire Agreement between the government of Angola and UNiTA, Heffes and Kotlik, 'Special Agreements as a Means of Enhancing Compliance with IHL in NonInternational Armed Conflicts: An Inquiry into the Governing Legal Regime,' n. 17. 
the Peace Agreement and add it as an annex to UNSC Resolution 2261 (2016) in order to give it the character of an "official document of the Security Council." 57

UNSC resolutions have been used to internationalize internal peace agreements in several cases. In general, the Security Council has shown support for internal peace agreements in cases where the UN had participated in the negotiation process. Examples include peace processes and agreements in Angola, ${ }^{58}$ Afghanistan, ${ }^{59}$ Nepal, ${ }^{60}$ Ivory Coast, ${ }^{61}$ Sudan, ${ }^{62}$ and Libya ${ }^{63}$ In these cases, the Council endorsed or welcomed the agreement, encouraged the parties to cooperate toward its implementation, and created or extended the mandate of UN military or political missions in the respective country.

In the Colombian case, the Security Council has adopted several resolutions regarding the peace agreement. First, Resolution 2261 (2016) established a 12month "political mission of unarmed international observers, responsible for the monitoring and verification of the laying down of arms." ${ }^{64}$ Then, Resolution 2307 (2016) welcomed the Final Agreement reached on 24 August 2016 (which was later rejected by popular vote) and approved the deployment of the

57 Gobierno de Colombia and FARC, 'Comunicado Conjunto No. 69.'

58 UNSC Resolution 1127 (1997), UN. Doc. S/RES/1127 (1997).

59 UNSC Resolution 1383 (2001), UN. Doc. S/RES/1383 (2001). It "Endorses the Agreement on provisional arrangements in Afghanistan" concluded by the participants in the UN Talks on Afghanistan held in Bonn in December 20o1. In this case, the negotiations were conducted under UN support, and the UNSC had previous resolutions and interventions on the matter.

6o UnSC Resolution 1740 (2007), UN. Doc. S/RES/1740 (2007), "Welcoming the signing on 21 November by the Government of Nepal and the Communist Party of Nepal (Maoist) of a Comprehensive Peace Agreement" and established a UN Political Mission in Nepal (UNMIN).

61 UNSC Resolution 1464 (2013), UN. Doc. S/RES/1464. It "Endorses the agreement signed by the Ivorian political forces in Linas-Marcoussis on 24 January 2003." A Conference of Heads of Stated on Côte d'Ivore was held in Paris right after the Agreement was concluded. This Conference was hosted by France, who, as permanent member of the UNSC sent an official letter to the Council submitting the peace agreement itself and the conclusions of the Conference of Heads of State in which they asked this endorsement.

62 UNSC Resolution 1590 (2005), UN. Doc. S/RES/1590 (2005), "Welcoming the signing of the Comprehensive Peace Agreement between the Government of Sudan (Gos) and the Sudan People's Liberation Movement/Army (SPLM/A) in Nairobi, Kenya on 9 January 2005" and establishes a UN Mission in Sudan (UNMIS) (with military component).

63 UNSC Resolution 2259 (2015), UN. Doc. S/RES/2259 (2015). It "Welcomes the signature on 17 December 2015 of the Libyan Political Agreement of Skhira", and "Endorses the Rome Communiqué of ${ }_{13}$ December 2015 to support the Government of National Accord as the sole legitimate government of Libya."

64 UN Security Council, 'Resolution 2261 (2016), Pub. L. No. S/REs/2261 (2016). 
political monitoring mission created by Resolution 2261. ${ }^{65}$ Later, Resolution 2366 (2017) welcomed the new Final Agreement signed on 24 November 2016 and established a new Verification Mission to monitor the reintegration process and the implementation of the Agreement. ${ }^{66}$ Finally, through Resolutions 2377 (2017), 2381 (2017), 2435 (2018), and 2487 (2019) the Council defined operational aspects of the Verification Mission and expanded and renewed its mandate.

Additionally, as agreed in the Joint Communiqué No. 69, on 24 March 2017 Colombia deposited a letter before the UN Secretary-General in which the President of the Republic, after thanking the Organization for its support to the peace process, stated: "I would also like to officially express the Colombian Government's good faith through a unilateral State declaration, and herewith submit the full text of the Final Agreement." ${ }^{\prime 67}$

For some authors, UNSC resolutions lend international legal force to the agreements they support. For Bell, "Security Council resolutions can be used to bring the force of law to peace agreement commitments, establishing mechanisms for monitoring compliance that stand independently of the status of the agreement itself, which nevertheless forms their raison dêtre." 68 Roucounas further affirms that through its incorporation in a Security Council resolution, the peace agreement becomes "an act of the international organization and operates as such towards the parties and towards the international community as a whole." 69

An illustrative case for this discussion is given by the peace agreement between the Government of Angola and União Nacional para a Independência Total de Angola (UNITA). Under UN mediation, the parties signed two documents that were circulated as UN documents. UNITA failed to accomplish its obligations and consequently reactivated the risk of violence. In reaction, by Resolution 1127 (1997), the Security Council demanded UNITA to immediately implement its obligations under the peace agreement, invoking Chapter viI of the UN Charter. ${ }^{70}$ Analyzing this case, Kooijmans argued:

\footnotetext{
65 UN Security Council, Resolution 2307 (2016).

66 UN Security Council, Resolution 2366 (2017).

67 UN Secretary-General, 'Letter Dated 29 March 2017 from the Secretary-General Addressed to the President of the Security Council,' 29 March 2017, https://colombia.unmissions.org/ sites/default/files/s-2017-272_e.pdf Annex I.

68 Bell, 'Peace Agreements: Their Nature and Legal Status,' 394.

69 Emmanuel Roucounas, 'Peace Agreements as Instruments for the Resolution of Intrastate Conflicts,' in Conflict Resolution: New Approaches and Methods, by Unesco (Paris: UNESCO, 2000), 120-21. UNSC Resolution 1127 (1997), UN. Doc. S/RES/1127 (1997), section A.
} 
The fact that [the agreement] is concluded between a government and an insurrectionist party does not in itself detract from its international character. The United Nations as an organization of states has been deeply involved in the conflict, peace keeping forces have been deployed, the Secretary-General through his Special Representative has continuously mediated. If a settlement is reached which is co-signed by the SecretaryGeneral's Representative, the non-state entity must be assumed not only to have committed itself to its counterpart, the Government but also to the United Nations. ${ }^{71}$

However, in opposition to Kooijmans' opinion, the Special Court of Sierra Leone concluded that in this case the "action taken by the Security Council upon failure of a party to implement the peace agreement derives from Chapter VII of the UN Charter and not from the peace agreement."72 Indeed, the Security Council deemed that "the resulting situation in Angola constitutes a threat to international peace and security in the region" and cited this as the reason by which it acted "under Chapter VII of the Charter of the United Nations." ${ }^{33}$ As such, the enforceability of the obligations agreed upon by the parties did not derive from the agreement itself but from the UN Charter. Nonetheless, the peace agreement was used by the Security Council as a reference to determine UNITA's noncompliance.

The Security Council's endorsement of a peace agreement therefore does not by itself lend international legal value to such a deal. However, its endorsement has at least two important consequences. First, on a political level, the Council's seizing of the agreement and involvement in its implementationas in the case of Colombia through monitoring missions-raise international attention and can add pressure toward compliance. Second, on a legal level, in the case of a failure to meet the agreement obligations that raises a threat to international peace and security, the deal could be used as a parameter to determine obligations and eventual responsibilities before the Council acting under Chapter viI of the Charter.

Finally, the unilateral declaration made by the Colombian President at the time of depositing the Final Agreement before the Secretary-General requires

71 P.H. Kooijmans, 'The Security Council and Non-State Entities as Parties to Conflicts,' in International Law: Theory and Practice: Essays in Honour of Eric Suy, ed. Eric Suy and Karell Wellens (The Hague: Martinus Nijhoff Publishers, 1998), 338.

72 Special Court for Sierra Leone, The Appeals Chamber, Prosecutor v. Morris Kallon and Brima Bazzy Kamara, paragraph 39 . UNSC Resolution 1127 (1997), UN. Doc. S/RES/1127 (1997), section B. 
a special mention. In accordance with the Guiding Principles Applicable to Unilateral Declarations of States Capable of Creating Legal Obligations, which was adopted by the International Law Commission (ILC) in 2006, a public declaration made at the international level by the Head of State, Head of Government or Minister of Foreign Affairs, in which the will to be bound is expressed clearly and specifically, creates international legal obligations. The binding character of such a declaration is based on good faith, and other interested states "are entitled to require that such obligations be respected."74 According to these terms, independent of the annexation of the Agreement to a UNSC Resolution, the unilateral declaration made by the President on behalf of the State generates international legal obligations for Colombia. The Agreement therefore also attained international legal character by this means.

\subsection{Consequences of the Peace Agreement's International Legal Status}

Despite the parties' intention to give the Peace Agreement legal certainty through its legal internationalization, the terms by which it was delimitated following the plebiscite reduced the domestic effects of such a formula. As noted above, in Colombia duly ratified international treaties regarding IHRL and IHL have the same normative level as the Constitution, forming a constitutional block. However, the terms of Article 93 of the Colombian Constitution make clear that such a status is reserved to treaties stricto sensu. ${ }^{75}$ As such, even if the Peace Agreement can be considered an international agreement, as per the above analysis, it does not have the character of a treaty under the vCLT. Legally, this is the reason why the first formula proposed by the Government and the FARC incorporating the agreement into the constitutional block was problematic. In contrast, the Final Agreement did not invoke such a constitutional feature but rather the status of special agreement for the purposes of "its international validity."76

The international character of the Peace Agreement as a special agreement therefore does not imply per se any legal constraint to its domestic modification. The legal certainty of the Final Agreement ultimately depends on the constitutional reforms introduced to protect it. To this effect, as mentioned above, a constitutional amendment was adopted stating that all organs of the

74 International Law Commission, Guiding Principles Applicable to Unilateral Declarations of States Capable of Creating Legal Obligations, 2006.

75 Constitución Política de Colombia, Art. 93.

76 Government of Colombia and Farc, 'Final Agreement to End the Armed Conflict and Build a Stable and Lasting Peace,' 5 . 
State must act according to what was agreed on, "preserving the contents, commitments, the spirit and the principles of the Final Agreement," and that this provision will be in force for three presidential terms. ${ }^{77}$

Additionally, the same amendment included a provision according to which the contents of the Agreement related to the norms of IHL and fundamental rights "will be compulsory parameters of interpretation and a referent for the development and validity of the norms and laws developing and implementing the Final Agreement." ${ }^{\prime 8}$ Even if this provision did not give the Agreement an international effect at the domestic level, its content related to IHL and human rights became a parameter by which to interpret and develop the peace agreement. ${ }^{79}$ For all the above reasons, Bell considers the Colombian Peace Agreement to be something " 'hybrid' between international and constitutional law."80

Nonetheless, at the international level, the international legal status of the Peace Agreement can have important political and legal effects. In political terms, defining the peace deal as an international agreement increases the "reputation costs" for the parties involved in the case of non-compliance. ${ }^{81}$ In the Colombian case, the UNSC resolutions regarding the agreement have played a significant role, as the agreement has received the attention of the highest global body responsible for international peace and security. Though this cost could be higher for the State, the FARC also want to preserve the implicit degree of reputation and recognition attached to the legal status of the Peace Agreement. ${ }^{82}$

In legal terms, the international legal character of the Peace Agreement could have at least three consequences. First, the unilateral declaration made by the President on behalf of the Colombian State before the UN generated

77 Congreso de la República de Colombia, Acto Legislativo o2 de 2017, available at: http:// es.presidencia.gov.co/normativa/normativa/ACTO $\% 20 L E G I S L A T I V O \% 20 N^{\circ} \% 2002 \% 20$ DE\%2011\%2oDE\%2OMAYO\%2oDE\%2O2017.pdf.

78 Ibid.

79 This formula could capture the notion of "trans-textuality", proposed by Roucounas, according to which as peace agreements generally include obligations already enshrined by international law instruments, they will also become internationally binding. Roucounas, 'Peace Agreements as Instruments for the Resolution of Intrastate Conflicts,' $120-21$.

8o Bell, 'Lex Pacificatoria Colombiana: Colombia's Peace Accord in Comparative Perspective,' 169 .

81 Bell, On the Law of Peace, 139.

82 On the idea of the costs and benefits of the legal status of the peace agreement for nonstate actors, see: von Hehn, The Internal Implementation of Peace Agreements after Violent Intrastate Conflict, 53 . 
legal obligations in terms of the Guiding Principles proposed by the ILC in 2006. To that effect, any interested state-for instance, the guarantor countries-could invoke international obligations contracted by Colombia in the Peace Agreement. An announcement made in 2018 by the new political party that emerged from the transition of the FARC to civilian life is illustrative of this point: the party asked the UN to request an International Court of Justice's advisory opinion on the scope and effects of the unilateral declaration made by the President of the Republic in March 2017 regarding the Peace Agreement. ${ }^{83}$ Even though this request has not been followed, it shows the potential legal effects of such a unilateral declaration.

Second, as the special agreement constitutes a norm of IHL, the Agreement could eventually be considered as a parameter before the ICC in the case that a war crime was under its examination, and the commission of such a crime would have any relation with the agreement. This possibility is rare but theoretically conceivable.

Third, as a more likely consequence, the Peace Agreement can become a parameter by which to examine the State's responsibility before human rights bodies and courts. Regarding this point, von Hehn notes that "by including the applicability of human rights conventions in the peace package, countries also attract monitoring by the respective treaty bodies, enabling additional scrutiny of the implementation process outside of the main negotiations." ${ }^{44}$ Along same lines, Verucci suggests that since a special agreement is an international norm, it could be used, for example, to evaluate a state under the Universal Periodic Review. ${ }^{85}$

With respect to this third consequence, a concrete example of the use of a peace agreement as a parameter by international bodies is given by the InterAmerican Court of Human Rights. In the El Mozote case, the Court claimed that "when analyzing the compatibility of the Law of General Amnesty for the Consolidation of Peace with the international obligations arising from the American Convention and its application to the case," it is also necessary to consider "the provisions of Protocol II Additional to the 1949 Geneva Conventions, as well as of the specific terms in which it was agreed to end hostilities, which put an end to the conflict in El Salvador and, in particular, of

83 Caracol Radio. (2018). Farc pedirá opinión jurídica a la CIJ para implementación de los Acuerdos de Paz. Available at http://caracol.com.co/radio/2018/o1/14/nacional/ 1515906848_061576.html (accessed on 20 February 2019).

84 von Hehn, The Internal Implementation of Peace Agreements after Violent Intrastate Conflict, 57 .

85 Vierucci, 'Applicability of the Conventions by Means of Ad Hoc Agreements', 520. 
Chapter 1 ("Armed Forces"), section 5 ("End to impunity"), of the Peace Accord of January 16, 1992." ${ }^{\prime 6}$ In this case, the Court used a domestic peace agreement as a parameter by which to evaluate the state's responsibility under IHRL.

\section{Socioeconomic and Political Reforms}

As presented in Chapter 1, the object of jus post bellum is not only about ending armed conflict but building sustainable peace. Regarding NIACs, both purposes usually demand socioeconomic and political reforms. First, ending armed conflict requires social, economic, and political measures for the reintegration of former fighters. Second, building sustainable peace involves both socioeconomic and institutional recovery from the damages caused by armed conflict, as well as addressing the root causes of confrontation, which are commonly related to socioeconomic and political matters. All those questions are present in the 2016 Colombian Peace Agreement.

This chapter departed from presenting a general overview of the Colombian armed conflict. As seen, the origin of armed conflict in the country was deeply related to socioeconomic and political reasons. Guerrilla groups have invoked land concentration, rural poverty, and political exclusion as the original causes of the conflict. ${ }^{87}$ Additionally, the protracted confrontation brought other related elements such as the impact of forced displacement, landmines, and war economies-e.g. crops of illicit use. All those factors had to be addressed in a comprehensive way if parties wanted to negotiate a serious and lasting peace. And they did it.

This section is aimed at exploring how socioeconomic and political reforms adopted for transition in Colombia reveal legal and policy considerations responding to a framework of jus post bellum. Unlike the other sections of this chapter, which mainly assume a legal perspective, this one addresses policy aspects of peacebuilding related to removing the root causes of conflict and building a sustainable peace.

For that, the section presents the general international legal and policy framework applicable to socioeconomic and political reforms in transition. Then, it examines how those reforms are addressed in the Colombian Peace Agreement, broaching issues such as land access and rural development,

86 Inter-American Court of Human Rights, Case of the Massacres of El Mozote and nearby places v. El Salvador, Judgement of 25 October 2012 (2012), para. 284.

87 Government of Colombia and FARC, 'Final Agreement to End the Armed Conflict and Build a Stable and Lasting Peace,' 2. 
environmental protection, demining, the problem of crops of illicit use, and the reintegration of former fighters.

\section{$\mathbf{2 . 1}$}

\section{Legal and Policy Framework on Socioeconomic and Political Reforms for Transition to Peace}

Armed conflict affects social and economic development, deteriorates the environment, breaks social coexistence, and undermines democratic mechanisms and institutions. Moreover, in contexts of NIACs some of those problems existed before armed conflict started and, in most cases, they were the very cause of confrontation.

Therefore, addressing the root causes of armed conflict and building conditions for sustainable peace in transition from NIACs implies removing structural factors of exclusion and inequalities. As pointed out by Chetail, peacebuilding entails the responsibility 'to free individuals not only from 'fear' but also from 'need." 88 As such, "the concept of post-conflict peacebuilding is inextricably linked to the notion of a 'positive peace' describing a situation which is not only characterized by the absence of hostiles but by many other political, economic and social accomplishments." 89

This aim of positive peace involves several social, economic, and political measures, all of which entail legal considerations. As Schaller argues, "the establishment of conditions for a positive and durable peace is also inseparably linked to effectively guaranteeing human rights." ${ }^{90}$ In other words, building positive peace beyond the end of armed confrontation requires human rightsbased reforms addressing matters as poverty, marginalization, development, and democratic participation.

Different international legal instruments enshrine provisions applicable to socioeconomic and political reform in transitional contexts, under a human rights perspective. In general terms, the International Covenant on Civil and Political Rights (ICCPR) establishes the state's obligation to ensure to all people under its jurisdiction the full enjoyment of their civil and political rights. It mainly includes, for the purpose of this section, the right to political and social participation. ${ }^{91}$ Similarly, the International Covenant on Economic, Social, and

88 Chetail, 'Introduction,' 8.

89 Christian Schaller, 'Towards an International Legal Framework for Post-Conflict Peacebuilding,' Research Paper, German Institute for International and Security Affairs 3 (2009): 15 .

90 Schaller, 15 .

91 'International Covenant on Civil and Political Rights,' Pub. L. No. General Assembly Resolution 2200A (XXI), (1966) Art. 3 and 25. 
Cultural Rights (ICESCR) enshrines the state's obligation to ensure the enjoyment of all economic, social, and cultural rights, and to adopt all appropriate means for that purpose..$^{92}$ Analogous provisions can be found in other regional human rights instruments. ${ }^{93}$

Regarding soft law documents, there are several instruments related to social, economic, and cultural rights relevant to the context of peacemaking and peacebuilding. The UN Declaration on the Right to Development establishes that "The right to development is an inalienable human right by virtue of which every human person and all peoples are entitled to participate in, contribute to, and enjoy economic, social, cultural and political development, in which all human rights and fundamental freedoms can be fully realized." ${ }^{\prime 4}$ Additionally, it disposes that "Appropriate economic and social reforms should be carried out with a view to eradicating all social injustices."95

The UN Declaration on the Right to Peace underlines the positive dimension of peace as involving "mutual understanding, cooperation, and socioeconomic development," and for such a purpose recalls "the world commitment to eradicate poverty and to promote sustained economic growth, sustainable development and global prosperity for all, and the need to reduce inequalities within and among countries." ${ }^{\prime 96}$ In this line, the 2030 Agenda for Sustainable Development states that "There can be no sustainable development without peace and no peace without sustainable development." ${ }^{\prime 7}$

More recently, the 2018 UN Declaration on the Rights of Peasants and Other People Working in Rural Areas ${ }^{98}$ addressed the states' obligations under IHRL to ensure all human rights to people living in rural areas. This instrument is very revalent regarding peacemaking and peacebuilding in the contexts of NIACs, because of the special impact of armed conflict in the rural areas. At this regard, the Declaration states the right of peasants and rural people to

92 'International Covenant on Economic, Social and Cultural Rights,' Pub. L. No. General Assembly Resolution 2200A (XXI), (1966) Art. 2-3.

93 'European Convention for the Protection of Human Rights and Fundamental Freedoms' (1950); 'American Convention on Human Rights' (1969).

94 UN General Assembly, 'Declaration on the Right to Development,' Pub. L. No. A/Res/41/ 128 (1986) Art. 1.1.

$95 \quad$ UN General Assembly Art. 8.1.

96 UN General Assembly, 'Declaration on the Right to Peace,' Pub. L. No. A/Hrc/Res/32/28 (2016), 2-3.

97 UN General Assembly, 'Transforming Our World: The 2030 Agenda for Sustainable Development,' Pub. L. No. A/RES/70/1 (2015), 3.

98 UN General Assembly, 'Declaration on the Rights of Peasants and Other People Working in Rural Areas,' Pub. L. No. A /REs/73/165 (2019). 
have and "an adequate standard of living"99 and to live in conditions of "peace and dignity."100

In terms of disarmament, demobilization, and reintegration (DDR), several UN documents provide policy and legal considerations relevant to jus post bellum. UN reports and resolutions have consistently stressed on DDR "as a key element of stabilization in post-conflict situations to facilitate a society's transition from conflict to development;"101 the need to assume a comprehensive view of DDR programs ${ }^{102}$ and to integrate them to other components of the peacebuilding framework; ${ }^{103}$ and the adoption of differential considerations on DDR regarding women and children fighters. ${ }^{104}$ In addition, the UN approach to DDR identifies several IHL and IHRL provisions as applicable to DDR, mainly regarding civil and political rights, promoting access to education, health, employment and other economic, social, and cultural rights without discrimination, and the duty to ensure special protection to women and children in all circumstances. ${ }^{105}$

According to such a general framework, different socioeconomic and institutional aspects must be addressed in transition to establishing a sustainable peace. For instance, reforms aimed at creating socioeconomic development are fundamental for employing former fighters and providing them with an alternative livelihood (a fundamental condition for an effective reintegration), ${ }^{106}$ as well as for building conditions of wellbeing for the population, which can facilitate social integration and long-term stability. Similarly, institutional reforms aimed at empowering excluded groups and broadening civic and political participation are fundamental to reestablish civic trust, peaceful coexistence, and reconciliation.

Likewise, environmental protection is a fundamental dimension of peacebuilding. ${ }^{107}$ Armed conflict usually impacts the environment, which is also

99 UN General Assembly Art. 17.1.

100 UN General Assembly Art. 24.1.

101 Secretary-General's report on The Role of UN Peacekeeping in Disarmament, Demobilization and Reintegration, S/2000/101, of 11 February 2000, paras. 2 and 8.

102 Statement by the President of the Security Council, S/PRST/200o/10, of 23 March 2000.

103 Report of the Panel on UN Peace Operations, A/55/305; S/2000/809, of 21 August 2000.

104 Security Council Resolution 1325 (2000) on Women, Peace and Security; and Resolutions 1379 (2001), 1460 (2003) and 1539 (2004) on Children in Armed Conflict.

105 United Nations Disarmament, Demobilization and Reintegration Resource Center, The UN Approach to DDR, 2006, pp. 18-19.

106 Achim Wennmann, 'Economic Provisions in Peace Agreements and Sustainable Peacebuilding,' Négotiations 1, no. 11 (2009): 46.

107 Carsten Stahn, 'R2P and Jus Post Bellum. Towards a Polycentric Approach,' in Jus Post Bellum: Mapping the Normative Foundations, ed. Carsten Stahn, Jennifer Easterday, and 
irregularly exploited as a means to finance armed hostilities in the context of NIAC s. ${ }^{108}$ The environmental degradation caused by those situations can exacerbate violence, especially in contexts "where large parts of the population depend on land and renewable resources for their livelihood." 109 This situation imperils reconciliation and affects the conditions for effective post-conflict economic reconstruction. ${ }^{110}$ For these reasons, "environmental protection and the sustainable management of resources are important pathways to consolidate peace and promote long-term development."111

Finally, mine action is another critical element in post conflict transition and post-conflict reconstruction. ${ }^{112}$ In countries seriously affected by minefields during armed conflict, demining is a crucial element to restore livelihoods and contribute to peacebuilding. ${ }^{113}$ It facilitates the reintegration of former fighters (when employed as deminers, for instance) and the return of refugees and internally displaced persons, promotes cooperation and confidence-building, and improves safety, security, and economic revitalization. ${ }^{114}$

All the above components of the post-conflict socioeconomic and political reconstruction have a legal base, mainly under IHRL and IHL, in addition to several UN and soft law documents related to the rights to peace and development, and to peacebuilding in general. In the next item, we will see how such an international legal framework shaped transitional formulas in Colombia on this matter.

Jens Iverson (Oxford: Oxford University Press, 2014), 118; Easterday, 'Peace Agreements as a Framework for Jus Post Bellum,' 409; Cymie Payne, 'The Norm of Environmental Integrity in Post-Conflict Legal Regimes,' in Jus Post Bellum: Mapping the Normative Foundations, ed. Carsten Stahn, Jennifer Easterday, and Jens Iverson (Oxford: Oxford University Press, 2014), 502-18; Stahn, Iverson, and Easterday, Environmental Protection and Transitions from Conflict to Peace: Clarifying Norms, Principles, and Practices.

108 Gillett, 'Eco-Struggles: Using International Criminal Law to Protect the Environment During and After Non-International Armed Conflict,' 223.

109 Jennifer Easterday and Hana Ivanhoe, 'Conflict, Cash, and Controversy: Protecting Environmental Rights in Post-Conflict Settings,' in Environmental Protection and Transitions from Conflict to Peace: Clarifying Norms, Principles, and Practices, ed. Carsten Stahn, Jens Iverson, and Jennifer Easterday (Oxford: Oxford University Press, 2017), 274.

110 Gillett, 'Eco-Struggles: Using International Criminal Law to Protect the Environment During and After Non-International Armed Conflict,' 249; Hofmann and Rapillard, 'PostConflict Mine Action: Environment and Law,' 404.

111 Hofmann and Rapillard, 'Post-Conflict Mine Action: Environment and Law,' 397.

112 Hofmann and Rapillard, 'Post-Conflict Mine Action: Environment and Law.'

113 Hofmann and Rapillard, 397.

114 Hofmann and Rapillard, 418-19. 


\subsection{Socioeconomic and Political Reforms in the Colombian Peace Agreement}

The very name of the Final Agreement to End Armed Conflict and Build a Stable and Lasting Peace raises the parties' determination to address the root causes of the armed conflict, as a condition to build a sustainable peace in Colombia. In its introduction, the Agreement declares its rights-based approach, and its goal to contribute to greater territorial integration and greater social inclusion, as well as to strengthening democracy, bringing institutions to all over around the country, and ensuring that all the ideas can be expressed with full guarantees via politics and social conflicts can be resolved through institutional channels. ${ }^{115}$ In this way, the Agreement states as its final aim the full realization of all human rights for all people, ${ }^{116}$ and it considers itself as a guarantee of non-recurrence of violations of human rights. ${ }^{117}$

That explicit utterance of the rights-based approach to building sustainable peace is complemented with reiterated references to IHRL along the Agreement. ${ }^{118}$ The parties explicitly defined a commitment to make effective all human rights, according to the Colombian Constitution, to the ICCPR, the ICESCR, and the other IHRL treaties ratified by Colombia. ${ }^{119}$ As such, they openly attributed a role to international legal norms and standards to govern matters highly dependent on domestic political and practical considerations.

Having the elements presented above, the following are the main aspects referred to socioeconomic and political matters in the Colombian Peace Agreement.

First, the first chapter of the Peace Agreement is devoted to a comprehensive rural reform. This chapter understands rural problems in Colombia as a root cause of armed conflict, and the need to implement a comprehensive reform as a condition to build a sustainable peace. On this topic, the Agreement includes development programs for the structural transformation of the countryside, promoting an equitable relationship between rural and urban areas. ${ }^{120}$ It includes an ambitious program of rural infrastructure, connectivity, health,

115 Government of Colombia and FARC, 'Final Agreement to End the Armed Conflict and Build a Stable and Lasting Peace,' 6.

116 Government of Colombia and FARC, 2.

117 Government of Colombia and FARC, 132.

118 The Agreement contains 14 specific references to I HRL. See Government of Colombia and FARC, 'Final Agreement to End the Armed Conflict and Build a Stable and Lasting Peace.'

119 Government of Colombia and FARC, 190.

120 Government of Colombia and FARC, 22. 
education, housing, cooperative economy, income generation, progressive realization of the right to food, and land access.

Second, linked to rural development programs, the Agreement makes several references to environmental protection in the context of peacebuilding. In its preamble, the Agreement envisions a society in which peace allows to achieve sustainable development, protection of the environment, natural resources, and biodiversity. ${ }^{121}$ Then, it offers special land access and other benefits for peasants, rural victims, and communities who work to protect the environment, substitute crops of illicit use, and improve food production. ${ }^{122}$ Additionally, the deal calls for the protection of areas of special environmental interest with the participation of rural communities, looking for a sustainable development, in which the Agreement emphasizes on the special contribution of small-scale farmer and indigenous and Afro-descendent communities. ${ }^{123}$

Third, since political exclusion was at the heart of the root causes of armed conflict, in the same way as for the rural reform the parties dedicated a full chapter of the Agreement to political participation and democratic opening. Here, the parties agreed on rights and guarantees for the exercise of political opposition; a comprehensive security system for the exercise of politics; democratic mechanisms for citizen participation; guarantees for reconciliation, coexistence, and non-stigmatization; awareness-raising campaigns for nondiscrimination, pluralism, and the free debate of ideas; promoting greater participation in politics among the most excluded social sectors; and the political participation of former members of the guerrilla. ${ }^{124}$ This chapter also establishes a National Political Pact, aimed at reaching a commitment that arms will never again be used in politics and never again will violent organizations such as paramilitarism be promoted. ${ }^{125}$

Fourth, the Agreement contains a detailed and technical chapter on the ending of armed conflict, in which it describes the procedure for the laying down of arms and the socioeconomic and political reintegration of former fighters. It includes social, educational, and employment programs for demobilized persons, with special support for programs related to environmental conservation and demining. ${ }^{126}$ Additionally, the Agreement established the creation of a new political party in which former guerrilla leaders could promote the

\footnotetext{
121 Government of Colombia and FARC, $3^{-4}$.

122 Government of Colombia and FARC, 15.

123 Government of Colombia and FARC, 11.

124 Government of Colombia and FARC, 37-55.

125 Government of Colombia and FARC, 8o.

126 Government of Colombia and FARC, 75 .
} 
ideas they previously defended by arms. ${ }^{127}$ On this point, it is important to mention that the guerrilla did not accept the use of the expressions disarmament and demobilization, as they saw them as a kind of capitulation. Instead, the Agreement systematically uses the expressions of laying down of arms, and social, political, and economic reintegration.

Fifth, since crops of illicit use and drug-trafficking became one of the main fuels of armed violence in the last decades in Colombia, the parties in negotiation dedicated a full chapter of the Agreement to this matter. They created a comprehensive program for substitution of crops used for illicit purposes, integrated to the comprehensive rural reform. The deal looks at promoting community-based plans and alternative agrarian development, ensuring economic and social rights. ${ }^{28}$ Additionally, the Agreement promotes a human rights and public health-based approach to the problem of drugs, and the development of an international conference under the auspices of the UN to assess the policy counter drugs and discuss new approaches to the matter.

Sixth, being the FARC the main responsible of mine contamination in Colombia, ${ }^{129}$ the Agreement establishes the cooperation of former guerrilla members with demining, and the State's commitment to clean the territory from landmines. Demining is presented as a condition for a safe return of internally displaced people and for rural development and substitution of crops of illicit use. Contribution to demining is among the possible restorative sanctions to be imposed to former fighters by the Special Jurisdiction for Peace.

In addition to those measures, the Agreement contains several references to economic, social, and cultural rights, the reparation for their violation, ${ }^{130}$ and a Truth Commission's mandate to elucidate the impact of armed conflict over economic, social, and cultural rights. ${ }^{131}$ The Agreement also states that

127 Government of Colombia and FARC, 69.

128 Government of Colombia and FARC, 106.

129 Colombia has the 15th position on extent of mine-contaminated land in the world up to the end of 2016, and the FARC were considered the main producer of antipersonnel landmines in Colombia until the signature of the Peace Agreement. See International Campaign to Ban Landmines. Landmine Monitor 2017, available at https://reliefweb.int/ sites/reliefweb.int/files/resources/Landmine_Monitor_2017_Embargoed.pdf (accessed on 4 February 2019).

130 Government of Colombia and Farc, 'Final Agreement to End the Armed Conflict and Build a Stable and Lasting Peace,' 125.

131 Government of Colombia and FARC, 134. On this role of truth commissions addressing economic, social and cultural rights, see Lisa Laplante, 'Transitional Justice and Peace Building: Diagnosing and Addressing the Socioeconomic Roots of Violence through a Human Rights Framework,' International Journal of Transitional Justice 2, no. 3 (2008): $331-355$. 
all its socioeconomic and political measures seek the non-recurrence of the conflict and ensuring human rights for all. It indicates that the rural reform looks for the "guarantee of rights, including economic, social, cultural and environmental rights of the rural population," which "contributes to their well-being and quality of life."132 As for the political reform, the Agreement seeks "the exercise of political rights, the promotion of a democratic culture and of human rights and guarantees for reconciliation, coexistence, tolerance, non-stigmatization, and the guarantees for the mobilization and social protest."133 Finally, the Agreement refers to actions related to resolve the problem of drugs of illicit use as a way "to contribute to overcoming the conditions of poverty, marginalization and weak institutional presence" in the rural areas. ${ }^{134}$

As such, the Colombian Peace Agreement assumed a solid human rightsbased approach to socioeconomic and political reforms aimed at building peace. In many cases the deal explicitly refers to IHRL obligations and, in the others, it involves substantial human rights issues, even though they are not necessarily expressed in the logic of international human rights instruments. ${ }^{135}$ However, the most important element for the purpose of this analysis is the fact that the parties understood the need to address the root causes of the conflict and to create socioeconomic and political conditions for building sustainable peace, and that they did so acknowledging and invoking international human rights obligations. As such, the parties used an international frame of reference to design their specific approach, according to the conditions of their context, offering insights on the importance of a human rights-based approach to development and reconstruction in peacebuilding. These considerations offer elements to see the Colombian case as involving a principle of jus post bellum on reconstruction and transformation of the conditions for sustainable peace, as Chapter 3 will further analyze.

132 Government of Colombia and Farc, 'Final Agreement to End the Armed Conflict and Build a Stable and Lasting Peace,' 199.

133 Government of Colombia and FARC, 199.

134 Government of Colombia and FARC, 198.

135 On this point, Kastner sustains that "even though many agreements that do not explicitly refer to human rights deal, in their substance, with human rights issues. Provisions on power sharing, the electoral system and institutional reform, and access to natural resources typically address questions of injustice and inequality, without necessarily using the language and logic of international human rights instruments." Kastner, Legal Normativity in the Resolution of Internal Armed Conflict, 43. See also Christine Bell, Peace Agreements and Human Rights (Oxford: Oxford University Press, 2003), 302-3. 
The most visible influence of international law in peacemaking is related to criminal responsibility for serious crimes committed during armed conflict. Traditionally, most peace negotiations had concluded with general amnesties for people responsible for such crimes. Then, South Africa introduced an internationally accepted mechanism of conditional amnesties to reach truth and reconciliation, with no criminal sanctions. However, since the paradigmatic development of ICL during the 1990s, this matter has progressively changed. Today, full amnesties are prohibited for crimes under international law, and conditional amnesties do not have any clear framework. This context carries out big challenges for countries emerging from internal armed conflicts through peace negotiations.

Colombia has assumed different approaches on this matter. During peace negotiations conducted in the late 1980s and early 199os, blanket amnesties were granted to demobilized members of guerrillas. After the intensification of armed conflict during late 199os and early 200os, a demobilization process was agreed with paramilitary groups who accepted their submission to justice in exchange for lenient punishments. This model, created in 2005, looked at conciliating the international exigencies of justice with the practical needs of a negotiated demobilization. Now, after the $2012-2016$ peace process with the FARC, a comprehensive model of transitional justice was agreed on by the parties, combining amnesties, criminal responsibility, and alternative punishments.

The 2016 Peace Agreement explicitly states that its transitional justice model is aimed at accomplishing the State's international obligations under IHL, IHRL, and ICL, ${ }^{136}$ satisfying the victims' rights to truth, justice, and reparation. For that, a Special Jurisdiction for Peace was created to try armed conflict-related crimes under international and domestic law, when amnesty is not possible. However, the system adopts a restorative perspective and, in exchange of the accused's contribution to truth and reparation, sentences will determine alternative punishments primarily aimed at repairing victims and building peace.

This model of criminal responsibility has been welcomed by the ICc. The Court's Prosecutor "note[d], with satisfaction, that the final text of the peace agreement excludes amnesties and pardons for crimes against humanity and

136 Government of Colombia and Farc, 'Final Agreement to End the Armed Conflict and Build a Stable and Lasting Peace,' 2, 129 . 
war crimes under the Rome Statute."137 Similarly, the President of the Court affirmed that the Colombian transitional justice model shows that peace and justice are not incompatible. ${ }^{138}$

Considering said elements, this section is divided into three parts. The first part presents the legal framework on amnesties at the end of NIACs and the duty to prosecute international crimes. The second part addresses the discussion on conciliating the needs of peace and the requirements of justice in transitional settings. And the third part explains the Colombian approach to criminal responsibility in a negotiated transition by observing applicable international legal standards.

\subsection{Legal Framework on Amnesties and Criminal Responsibility}

Both amnesty and criminal prosecution have international legal foundation. Amnesties are part of the instruments envisaged by IHL for the exit of armed conflict, but they cannot be used to evade the international legal obligation to prosecute serious crimes committed during armed conflict, which is a duty under IHL, IHRL, and ICL. As such, this item presents the legal framework on both amnesties and criminal responsibility for serious crimes, to then analyze its application in transition from armed conflict to peace and its application in the Colombian case.

\subsubsection{Amnesties at the End of NiAcs}

Since the XVIII century, Kant stated that "the very concept of peace entails the idea of amnesty." 139 This notion has prevailed in most peace agreements ending armed conflicts in the following two centuries.

Regarding NIAC s, Article 6(5) of 1977 Additional Protocol II to 1949 Geneva Conventions states that: "At the end of hostilities, the authorities in power shall endeavour to grant the broadest possible amnesty to persons who have participated in the armed conflict, or those deprived of their liberty for reasons related to the armed conflict, whether they are interned or detained." The ICRC considers this provision as a customary rule. ${ }^{140}$

137 Office of the ICC Prosecutor, 'Statement of ICC Prosecutor, Fatou Bensouda, on the Conclusion of the Peace Negotiations between the Government of Colombia and the Revolutionary Armed Forces of Colombia'.

138 'La Presidenta de La CPI: “Colombia Demuestra Que Paz y Justicia No Son Incompatibles", Agencia EFE, 1 July 2017, https://www.efe.com/efe/america/portada/la-presidenta-de-cpicolombia-demuestra-que-paz-y-justicia-no-son-incompatibles/200ooo64-3313655.

139 Kant, Immanuel. Metaphysic of Morals, $1797, \S 58$, quoted by Ambos, 'The Legal Framework of Transitional Justice,' 27.

140 Jean-Marie Henckaerts and Louise Doswald-Beck, Customary International Humanitarian Law. Volume I: Rules (Cambridge: Cambridge University Press, 2005). Rule 159. 
Analyzing the rationale behind such a provision, Kreß and Grover point out that the norm looks at offering "an incentive for non-State fighters to conduct the hostilities in accordance with the law of non-international armed conflict." ${ }^{141}$ Broomhall suggests that this provision "is intended primarily to discourage the prosecution under ordinary criminal law."142 In a different view, Mégret affirms that encouraging amnesties for rebels goes beyond a humanitarian purpose and it raises "the difficult legal question of which rebellions more generally conform to a sort of non-state jus ad bellum, and would reward those that do."143

Nonetheless, in a more functional perspective, amnesties play a fundamental role in peacemaking. In its 1987 Commentary on Additional Protocol II, the ICRC considered that the object of this provision on amnesties "is to encourage gestures of reconciliation which can contribute to reestablishing normal relations in the life of a nation which has been divided." ${ }^{144}$ Certainly, fighters who know that they will face a criminal "retribution will often consider that they have nothing to lose and fight to the end."145 Thus, in contexts of NIAC s waiver of punishment may be essential to restore peace and facilitate reconciliation. ${ }^{146}$ As such, amnesties are mainly an incentive for rebels to agree to peace.

Pursuing that objective, the international community has encouraged and supported amnesties in several transitions from NIACs around the world. ${ }^{147}$ In cases such as South Africa, Angola, Croatia, and Afghanistan the UN Security Council and the General Assembly explicitly called governments to grant amnesties or welcomed those that were agreed by the parties through

141 Kreß and Grover, 'International Criminal Law Restraints in Peace Talks to End Armed Conflicts of a Non-International Character,' 49.

142 Bruce Broomhall, International Justice and the International Criminal Court: Between Sovereignity and the Rule of Law (Oxford: Oxford University Press, 2003), 96.

143 Fédéric Mégret, 'Should Rebels Be Amnestied?', in Jus Post Bellum: Mapping the Normative Foundations, ed. Carsten Stahn, Jennifer Easterday, and Jens Iverson (Oxford: Oxford University Press, 2014), 539.

144 ICRC, Commentary of 1987 on Protocol Additional II (Geneva, 1987), para. 4618.

145 Charles Garraway, 'The Relevance of Jus Post Bellum: A Practitioner's Perspective,' ed. Carsten Stahn and Jann Kleffner (The Hague: T.M.C. Asser Press, 2008), 159.

146 Gerhard Werle, Principles of International Criminal Law (Oxford: Oxford University Press, 2014), 89.

147 Michael Scharf, 'The Letter of the Law: The Scope of the International Legal Obligation to Prosecute Human Rights Crimes,' Law and Contemporary Problems 59, no. 4 (1996): 41. On this line, Jeffery describes the essentially political functional purpose of amnesties Renée Jeffery, Amnesties, Accountability, and Human Rights (Philadelphia: University of Pennsylvania Press, 2014), 35-49. 
legislation or peace agreements. ${ }^{148}$ In none of these cases the international community asked for conditions or limitations for those amnesties.

However, the UN approach to amnesties changed right after the conclusion of the 1998 ICC Statute. In 1999 the Lomé Peace Agreement in Sierra Leone included an unconditional and complete amnesty for the rebels. ${ }^{149}$ The agreement was signed by international witnesses, including the Special Representative of the UN Secretary-General, who appended a disclosure stating that the UN would understand the amnesty provision contained in the agreement as not applicable to international crimes of genocide, crimes against humanity, and war crimes. ${ }^{150}$ After a resumption of hostilities, and mediating a request from the government to the UN, the Special Court for Sierra Leone was set up in 2002 to try people responsible for international crimes committed during the armed conflict. ${ }^{151}$

On this point, the ICRC highlights that even though Article 6(5) of Additional Protocol II does not mention any exclusion, the provision "could not be construed to enable war criminals, or those guilty of crimes against humanity, to evade punishment."152 As such, the customary rule on amnesties at the end of

148 See UN Security Council Resolutions 473 (1980), 1055 (1996), 1064 (1996), 1120 (1997); UN General Assembly Resolutions 47/141 (1992), 48/152 (1993), 49/207 (1994).

149 Art. IX.3 of the 19 May 1999 Lomé Agreement: "To consolidate the peace and promote the cause of national reconciliation, the Government of Sierra Leone shall ensure that no official or judicial action is taken against any member of the RUF, ex-AFRC, ex-SLA or $\mathrm{CDF}$ in respect of anything done by them in pursuit of their objectives as members of those organizations." Available at Peace Accords Matrix, https://peaceaccords.nd.edu/ provision/amnesty-lom-peace-agreement.

150 In his Seventh Report on the UN Observer Mission in Sierra Leone, the Secretary-General stated that "I instructed my special representative to sing the agreement with the explicit proviso that the United Nations holds the understanding that the amnesty and pardon in article IX of the agreement shall not apply to international crimes of genocide, crimes against humanity, war crimes and other serious violations of humanitarian law" Seventh Report of the Secretary-General on the United Nations Observer Mission in Sierra Leona, Security Council, UN Doc. S/1999/836, 30 July 1999, para. 7. For a discussion on this UN disclosure see William Schabas, 'Amnesty, the Sierra Leone Truth and Reconciliation Commission and the Special Court for Sierra Leone,' University of California Davis Journal of International Law and Policy 11 (2004): 145-169; Simon Chesterman, 'Rough Justice: Establishing the Rule of Law in Post-Conflict Territories', Ohio State Journal on Dispute Resolution 20, no. 1 (2005): 69-98.

151 UN Security Council Resolution 1315 (2000), UN. Doc. S/RES/1315 (2000).

$15^{2}$ Henckaerts and Doswald-Beck, Customary International Humanitarian Law. Volume I: Rules, 612. The ICRC endorses this opinion noting that it was expressed by the URSS delegation during the Diplomatic Conference leading to the adoption of the Additional Protocols on 7 June 1976 . 
NIAC s must be in harmony with the customary duty to prosecute crimes prohibited under international law, ${ }^{153}$ as the following items show.

\subsubsection{The Duty to Prosecute International Crimes}

Current international law has established a state's duty to prosecute serious violations of human rights and IHL. This obligation is explicitly enshrined by the 1949 Geneva Conventions, ${ }^{154}$ the 1948 Genocide Convention, ${ }^{155}$ the 1984 Convention against Torture, ${ }^{156}$ and the 2006 Convention against Enforced Disappearance. ${ }^{157}$ According to these conventions, states parties have the international obligation to bring to justice people under their jurisdiction who have committed conducts prohibited by those instruments.

The rationale behind this duty is that international crimes constitute offenses to humanity, and their prosecution is a matter of international concern to prevent impunity on those conducts. ${ }^{158}$ As such, the UNSC created the

153 Henckaerts and Doswald-Beck, Customary International Humanitarian Law. Volume I: Rules. Rules 158 and 159. At this point, Rule 159 explicitly includes the exception: "At the end of hostilities, the authorities in power must endeavor to grant the broadest possible amnesty to persons who have participated in a non-international armed conflict, or those deprived of their liberty for reasons related to the armed conflict, with the exception of persons suspected of, accused of or sentenced for war crimes."

154 First Geneva Convention, Article 49; Second Geneva Convention, Article 5o; Third Geneva Convention, Article 129; Fourth Geneva Convention, Article 146.

155 'Convention on the Prevention and Punishment of the Crime of Genocide' (1948). Articles 1 and 7 .

156 'Convention against Torture and Other Cruel, Inhuman or Degrading Treatment or Punishment,' Pub. L. No. General Assembly Resolution 39/46 (1984). Article 7. At this point, the Committee against Torture has expressly affirmed the incompatibility of amnesty laws for acts of torture with the obligations enshrined by the Convention. See Conclusions and Recommendations Azerbaijan, A/55/44, para. 69 (17 November 1999); Peru, A/55/44, para. 61 (15 November 1999).

157 'International Convention for the Protection of All Persons from Enforced Disappearance' (2006). Articles 6, 7 and 11.

$15^{8}$ Grant Niemann, 'International Criminal Law Sentencing Objectives,' in Criminal Justice in International Society, ed. Willem de Lint, Marinella Marmo, and Nerida Chazal (New York: Routledge, 2014), 135. In this line, talking about crimes against humanity, the ICTY stated that: "Crimes against humanity are serious acts of violence which harm human beings by striking what is most essential to them: their life, liberty, physical welfare, health, and dignity. They are inhumane acts that by their extent and gravity go beyond the limits tolerable to the international community, which must perforce demand their punishment. But crimes against humanity also transcend the individual because when the individual is assaulted, humanity comes under attack and is negated. It is therefore the concept of humanity as victim which essentially characterises crimes against humanity." ICTY, Prosecutor v. Erdemovic, Sentencing Judgment, Case No. IT-96$22 \mathrm{~T}$ (November 29, 1996), para. 28. 
International Criminal Tribunals for former Yugoslavia ${ }^{159}$ and for Rwanda ${ }^{160}$ to prosecute international crimes committed in those contexts. Later, this idea was codified in a permanent way in the 1998 Statute of the ICC, to ensure that when the involved state does not prosecute international crimes, an international court will assume such a task.

Connecting this duty of prosecution with the prohibition to grant amnesties for serious violations of human rights and IHL has been a contribution of the jurisprudence of international human rights courts and bodies, which have considered such a prohibition as a part of the states' positive obligations under IHRL. Since 1992, the Inter-American System of Human Rights has developed a solid jurisprudence on the prohibition of domestic amnesties for serious crimes. ${ }^{161}$ The Inter-American Commission on Human Rights has consistently concluded that laws granting amnesties for serious violations of human rights are incompatible with the Inter-American human rights instruments, deciding cases on Argentina, ${ }^{162}$ Chile, ${ }^{163}$ El Salvador, ${ }^{164}$ Peru, ${ }^{165}$ and Uruguay-where

159 UN Security Council. Resolution 823(1993), Pub. L. No. S/REs/827.

161 As du Bois-Pedain highlights, this jurisprudence constitutes a "regional development that is reflected not only in the jurisprudence of treaty bodies under the American Convention of Human Rights, but also in decisions of the higher courts and in constitutional documents in the region that invalidate amnesty law for serious human rights violations." Antje du Bois-Pedain, Transitional Amnesty in South Africa (Cambridge: Cambridge University Press, 2007), 316. In the same line, taking about Latin America, Roht-Arriaza says: "Even if the evidence worldwide is more ambiguous, a rejection of amnesty seems to be the overwhelming trend in this region." Naomi Roht-Arriaza, 'After Amnesties Are Gone: Latin American National Courts and the New Contours of the Fight against Impunity,' Human Rights Quarterly 37 (2015): 344.

162 Inter-American Commission on Human Rights, Report No. 28/92, Cases 10.147, 10.181, 10.240, 10.262, 10.309 and 10.311 (Argentina), 2 October 1992.

163 Inter-American Commission on Human Rights, Report No. 34/96, Cases 11.228, 11.229, 11.231 and 11.282 (Chile), Report No. 36/96, Case 10.843, 15 October 1996, para. 105 (Chile), 15 October 1996; Report No. 25/98, Cases 11.505, 11.532, 11.541, 11.546, 11.549, 11.569, 11.572, $11.573,11.585,11.595,11.562,11.567$ and 11.705 (Chile), 7 April 1998, para. 101.

164 Inter-American Commission on Human Rights, Report No. 26/92, Case 10.287, Las Hojas Massacre (El Salvador), 24 September 1992; Report No. 1/99, Case 10.480 Lucio Parada and Others (El Salvador), 27 January 1999 (In this case the Commission expressly rejected the application of amnesty for violations of $\mathrm{IHL}$, referring that the provision on amnesty enshrined by Art. 6(5) of Additional Protocol I does not apply for violation of the laws of war, see para. 115-116); Report No. 136/99, Case 10.448, Ignacio Ellacuria S.J. and Others (El Salvador), 22 December 1999; Report No. 37/oo, Case 11.481, Monsignor Oscar Arnulfo Romero (El Salvador), 13 April 2000.

165 Inter-American Commission on Human Rights, Report No. 1/96, Case 10.559, Chumbivilcas (Peru), 1 March 1996; Report no. 38/97, Case 10.548, Hugo Bustos Saavedra (Peru), 16 
the law on amnesty was even previously declared constitutional by the Uruguayan Supreme Court and approved by a national referendum. ${ }^{166}$ In all those cases, the Commission recommended to the respective states to adopt all necessary measures to clarify the facts and identify those responsible for human rights violations, reversing amnesty and pardon laws.

In 1998, the Inter-American Court of Human Rights defined impunity as "the total lack of investigation, prosecution, capture, trial and conviction of those responsible for violations of the rights protected by the American Convention," and reiterated the correspondent obligation of states to combat it by all legal means at their disposal. ${ }^{167}$ Following this jurisprudence, in 2001 the Court concluded that an amnesty law precludes the "access to justice and prevents the victims and their next of kin from knowing the truth and receiving the corresponding reparation." 168 As such, the Court decided that "the said laws lack legal effect and may not continue to obstruct the investigation of the grounds on which this case is based or the identification and punishment of those responsible, nor can they have the same or a similar impact with regard to other cases that have occurred."169 These decisions had domestic impacts and led states to derogate amnesty laws and prosecute former political and military leaders responsible for human rights abuses in Latin America. ${ }^{170}$

Although previous decisions on the matter were referred to post-dictatorial amnesties, in 2012 the Inter-American Court held the same view regarding amnesties after NIAC s. In the case Massacres of El Mozote the Court considered that even though Additional Protocol II contemplates amnesties at the end of armed conflict, they cannot be applied to international crimes, as El Salvador

October 1997, para. 46-47; Report No. 42/97, Case 10.521, Angel Escobar Jurador (Peru), 19 February 1998, para. 32-33.

166 Inter-American Commission on Human Rights, Report 29/92, Cases 10.029, 10.036, 10.145, 10.305, 10.372, 10.373, 10.374 and 10.375 (Uruguay), 2 October 1992.

167 Inter-American Court of Human Rights, Paniagua Morales et al. Case, Judgment of 8 March 1998 (1998), para. 133 .

168 Inter-American Court of Human Rights, Barrios Altos v. Peru, Judgement 25 November 2003 (2003), para. 43.

169 Inter-American Court of Human Rights, Judgement 25 November 2003 paragraph 44.

170 Some examples include Argentina (La Nacion, Diputados derogó la obediencia debida, 25 March 1998, https://www.lanacion.com.ar/politica/diputados-derogo-la-obedienciadebida-nid9150o, accessed on 10 March 2017); Chile (Publico, Chile deroga el decreto ley de amnistía aprobado por la dictadura, 12 September 2014, https://www.publico.es/ internacional/chile-deroga-decreto-ley-amnistia.html, accessed on 10 March 2017); El Salvador (El Nuevo Herald, Supremo salvadoreño deroga Ley de Amnistía, 10 July 2016, https://www.elnuevoherald.com/noticias/mundo/america-latina/article89949847.html, accessed on 10 March 2017). 
did through a law of amnesty. ${ }^{171}$ Similarly, the Human Rights Committee, in its concluding observations on Lebanon, expressed its concern for the amnesty granted to civilian and military personnel for human rights violations occurred during the civil war. For the Committee, "[s] uch a sweeping amnesty may prevent the appropriate investigation and punishment of the perpetrators of past human rights violations, undermine efforts to establish respect for human rights, and constitute an impediment to efforts undertaken to consolidate democracy."172 This position was developed in General Comments $20^{173}$ and $31,{ }^{174}$ where the Committee affirmed that failure to bring to justice perpetrators of human rights violations constitutes a separate breach of the ICCPR.

Owing to the consistent development of this obligation, the ICRC has identified the obligation to prosecute war crimes as a customary norm, ${ }^{175}$ which has been extended to crimes of genocide and crimes against humanity. ${ }^{176}$ Cassese even sustains that "international rules prohibiting and criminalizing a conduct that amounts to the most serious international crimes are peremptory in nature."177

These conventional, jurisprudential, and customary elements have therefore raised a prohibition to grant amnesties for international crimes in peace agreements. In his 2004 Report on the Rule of Law and Transitional Justice, the UN Secretary-General recommended: "that peace agreements and Security Council resolutions and mandates: [...] (c) Reject any endorsement of amnesty for genocide, war crimes, or crimes against humanity, [...] [and] ensure that

171 Inter-American Court of Human Rights, Case of the Massacres of El Mozote and nearby places v. El Salvador, Judgement of 25 October 2012 paragraphs 283-296, para. 283-296.

172 Human Rights Committee, Concluding Observations on Lebanon, CCPR/C/79/Add.78, 5 May 1997, para. 12.

173 Human Rights Committee, General Comment No. 20: Article 7 ICCPR (Prohibition of torture, or other cruel, inhuman or degrading treatment or punishment) (10 March 1992): "Some States have granted amnesty in respect of acts of torture. Amnesties are generally incompatible with the duty of States to investigate such acts; to guarantee freedom from such acts within their jurisdiction; and to ensure that thy do not occur in the future," para. 15 .

174 Human Rights Committee, General Comment No. 31: The Nature of the General Legal Obligation Imposed on States Parties to the Covenant, CCPR/C/21/Rev.1/Add.13 (2004): "As with failure to investigate, failure to bring to justice perpetrators of such violations could in and of itself give raise to a separate breach of the Covenant," para. 18.

175 Henckaerts and Doswald-Beck, Customary International Humanitarian Law. Volume I: Rules. Rule 158.

176 Kreß and Grover, 'International Criminal Law Restraints in Peace Talks to End Armed Conflicts of a Non-International Character,' 47.

177 Cassese, 'The Special Court and International Law The Decision Concerning the Lomé Agreement Amnesty,' 1140. 
no such amnesty previously granted is a bar to prosecution before any United Nations-created or assisted court."178 This report reaffirmed the SecretaryGeneral's disclosure regarding the 1999 Sierra Leone's Peace Agreement. Developing this notion, the 2005 UN Updated Set of Principles to Combat Impunity reiterated that: "[e]ven when intended to establish conditions conducive to a peace agreement or to foster national reconciliation, amnesty cannot benefit the perpetrators of serious crimes under international law."179

\subsection{Conciliating Peace and Justice in Peace Negotiations}

From the legal framework presented above, we can conclude that both amnesties at the end of NIACs and criminal accountability for international crimes are normatively supported and required in peace negotiations. ${ }^{180}$ On the one hand, to negotiate peace some level of amnesty is necessary. On the other hand, to protect the rule of law and victim's rights, justice must be ensured for serious violations of human rights and IHL. Conciliating this tension in a negotiated transition from armed conflict to peace is a central challenge in NIAC s. ${ }^{181}$

On this topic, the 2008 Nuremberg Declaration on Peace and Justice noted how the fight against impunity became a principle of international law that "has changed the parameters for the pursuit of peace."182 However, the Declaration highlights that peace and justice must be complementary, and the "question can never be whether to pursue justice, but rather when and how." In a similar view, former UN Secretary-General Ban Ki-Moon pointed out in 2009 that: "the debate on how to 'reconcile' peace and justice or how to 'sequence' them has lasted more than a decade. Today, we have achieved a conceptual

${ }_{17}$ UN Secretary-General, 'Report of the Secretary-General on the Rule of Law and Transitional Justice in Conflict and Post-Conflict Societies,' para. 64.

179 UN Commission on Human Rights, 'Updated Set of Principles for the Protection and Promotion of Human Rights through Action to Combat Impunity,' Pub. L. No. E/CN.4/ 2005/102/Add.1 (2005). Principle 24. On this line, Kulkarni presents an overview into the recent developments on criminal justice for conflict-related violations, noting that impunity continues to weaken due to a growing acceptance of the duty of states to prosecute international crimes, and the consideration of amnesties for such crimes as not legally valid. Anupma Kulkarni, 'Criminal Justice for Conflict-Related Violations. Developments during 2014,' in Peace and Conflict 2016, ed. David Backer, Ravi Bhavnani, and Paul Huth (New York: Routledge, 2016), 192-209.

18 o Bell, On the Law of Peace, 241.

181 Negotiated transitions face many constraints. This book is mainly focused on the normative and political aspects to be considered. For an overview on other constraints influencing transitions, see Jon Elster, Closing the Books: Transitional Justice in Historical Perspective (Cambridge: Cambridge University Press, 2004), 188-215.

182 UN General Assembly, Nuremberg Declaration on Peace and Justice. Principle 2. 
breakthrough: the debate is no longer between peace and justice but between peace and what kind of justice."183

Defining the levels and conditions of justice is a serious challenge in negotiated transitions. In a peace process ending a NIAC, four basic premises must be considered when deciding how to deal with crimes committed during the conflict. First, parties in negotiation, even if responsible for serious crimes, will hardly accept prison as a result of their talks. ${ }^{184}$ Second, even if a state wanted to pursue all the crimes committed during the conflict, their dimension generally exceeds its prosecutorial capacities. ${ }^{185}$ Third, amnesties are a fundamental legal instrument in transition, but at the current state of international law they only can be granted for offenses other than international crimes. Four, the multiplicity of actors and factors involved in a NIAC makes retributive justice insufficient for the needs of political and social reconciliation.

On this point, we could differentiate two levels of amnesty. For people involved in minor crimes related to armed conflict, full and unconditional amnesty is allowed. But in other cases, in principle, amnesties could only be admitted if they are conditioned to revealing truth and cooperating with reparation and reconciliation. ${ }^{186}$ That was the South African approach, where

183 Ban Ki-Moon, 'Secretary-General's Remarks on the 6oth Anniversary of the Geneva Conventions' (Ministerial Working Session hosted by the Government of Switzerland to mark the 6oth Anniversary of the Geneva Conventions, Geneva, 26 September 2009), https://www.un.org/sg/en/content/sg/statement/2009-o9-26/secretary-generals -remarks-ministerial-working-session-hosted (accessed on 15 June 2018).

184 Goldstone notes how negotiations would had been impossible in South Africa if those responsible for the apartheid had been expected to go to prison. Richard Goldstone, 'Past Human Rights Violations: Truth Commissions and Amnesties or Prosecutions,' Northern Ireland Legal Quarterly 51, no. 2 (2000): 168.

185 In this line, the Sierra Leone Truth and Reconciliation Commission notes that even if it would be desirable to prosecute perpetrators of serious human rights abuses, "amnesties should not be excluded entirely from the mechanisms available to those attempting to negotiate a cessation of hostilities after periods of brutal armed conflict. Disallowing amnesty in all cases would be to deny the reality of violent conflict and the urgent need to bring such strife and suffering to an end." Sierra Leone Truth and Reconciliation Commission Reports, vol. $3_{3}^{B}$, Chapter 6, "The TrC and the Special Court for Sierra Leone," p. 365 , para. 11 .

186 As noted by Braithwaite, "there is no objection in principle to amnesties following wars, so long as they are amnesties that contribute to the ending of war, so long as all stakeholders are given a voice in the amnesty negotiations, so long as those who benefit from amnesties are willing to show public remorse for their crimes and to commit to service to the new nation and its people to repair some of the harm they have done." John Braithwaite, Restorative Justice \& [and] Responsive Regulation (Oxford: Oxford University Press, 2002), 203. In the same line, the Transitional Justice Institute notes that "opinio juris from domestic and hybrid courts together with state practice on amnesties does not reflect an 
amnesties were internationally admitted because of their contribution to contain and prevent future human rights violations, ${ }^{187}$ and to achieve full disclosure of all relevant facts. ${ }^{188}$

Following that experience, several transitional processes around the world have incorporated truth commissions to deal with past human rights violations, granting amnesties in exchange of contributing to truth and reconciliation. ${ }^{189}$ This practice is grounded on the concept of restorative justice, ${ }^{190}$ which proposes a comprehensive approach to justice aimed at restoring the relationships between the perpetrator, the victim, and the society, instead of just punishing the first. ${ }^{191}$ At the time that consensus around the complementarity between peace and justice has been achieved, most authors agree that in post-conflict contexts judicial responses are insufficient. ${ }^{192}$ As Freeman and

established, explicit and categorical customary prohibition of amnesties for international crimes;" and they are legitimate when offenders are required to contribute to truth, reparation, and reconciliation. Transitional Justice Institute, The Belfast Guidelines on Amnesty and Accountability (Belfast: University of Ulster, 2013), 12.

187 du Bois-Pedain, Transitional Amnesty in South Africa, 335.

188 Henckaerts and Doswald-Beck, Customary International Humanitarian Law. Volume I: Rules. Rule 159 .

189 Kerry Clamp, Restorative Justice in Transition (London: Routledge, 2014), 71.

190 Porter points out that if the purpose is to achieve peace, restorative justice seems more adequate than retributive justice. This is the approach we should follow if the idea is to "give priority to victims in need of healing" and "building or restoring reconciled relationships" Elisabeth Porter, Peacebuilding: Women in International Perspective (London: Routledge, 2007), 20. In this line, Orozco Abad notes that in contexts of horizontal violence-where different actors are responsible of causing the violence, as it is the case of Colombia-, restorative mechanisms must prevail. Iván Orozco Abad, Sobre Los Límites de La Conciencia Humanitaria: Dilemas de La Paz y La Justicia En América Latina (Bogotá: Temis, 2005).

191 Rachel Kerr and Eirin Mobekk, Peace and Justice: Seeking Accountability after War (Cambridge: Polity, 2007); Porter, Connecting Peace, Justice and Reconciliation, 14. Ambos, 'The Legal Framework of Transitional Justice,' 23. On the idea of retributive justice as opposed to the needs of peace in transitional contexts, May notes that "Justice and peace are often discussed as opposed to each other. But the debate can be cashed out in terms of justice alone [...]. The justice that is sometimes opposed to peace is retributive justice." Larry May, 'Reparation, Restitution, and Transitional Justice,' in Morality, Jus Post Bellum, and International Law, ed. Larry May and Andrew Forcehimes (Cambridge: Cambridge University Press, 2012), 39.

192 As noted by Goldstone, "One must not expect too much from justice, for justice is merely one aspect of many-faceted approach needed to secure enduring peace in the transitional society." Richard Goldstone, 'Justice as a Tool for Peace-Making: Truth Commissions and International Criminal Tribunals,' New York University Journal of International Law and Politics 28, no. 3 (1996): 486. See also Sanam Anderlini, Women Building Peace: What They Do, What It Matters (Boulder: Lynne Rienner, 2007), 186. 
Djukic argue, "transitional justice is about the pursuit of a responsible form of justice that takes into account the parallel need for peace, democracy, security, and economic growth, precisely in order to deliver a form of justice worthy of the appellation." 193 Pursuing this broad set of goals, criminal retribution has generally been excluded from peace agreements.

Some authors argue that conditional amnesties could even play the function of punishment, when they are aimed at contributing to reconciliation, restoration of the rule of law, ${ }^{194}$ and creating a public record of past abuses. ${ }^{195}$ For Mallinder, practice shows that international courts' rejection to amnesties has "focused on automatic, unconditional amnesties that aimed to prevent investigations into human rights violations," but it does not refer to conditional amnesties. ${ }^{196}$

However, at the current development of international law, the admissibility of conditional amnesties for serious crimes is not clear. A blanket amnesty will never satisfy the complementarity test before the ICc. ${ }^{197}$ But it seems that, at present, not even a conditional amnesty will do so. In a letter sent in 2013 to the Colombian Constitutional Court during the exam of an amendment on transitional justice, the ICC Prosecutor affirmed that if a suspension of the criminal sanction implies that the most responsible for serious crimes do not spend time in prison, it would not satisfy the requirements of the ICC Statute. ${ }^{198}$ Two years later, in a more moderated position, the ICC Deputy Prosecutor affirmed in a

193 Freeman and Djukic, 'Jus Post Bellum and Transitional Justice,' 216.

194 Ruti Teitel, Transitional Justice (Oxford: Oxford University Press, 200o), 54.

195 du Bois-Pedain, Transitional Amnesty in South Africa, 322.

196 Louise Mallinder, 'Can Amnesties and International Justice Be Reconciled?', International Journal of Transitional Justice 1 (2007): 228. In another view on this point, Jeffery notes that generally amnesties have been overturned, circumvented or annulled in contexts where such a decision does not represent a risk to bring back conflict. Jeffery, Amnesties, Accountability, and Human Rights, 169.

197 Kreß and Grover, 'International Criminal Law Restraints in Peace Talks to End Armed Conflicts of a Non-International Character,' 70.

198 Prosecutor of the ICC. Letter of 26 July 2013. Constitutional Court, of 26 July 2013, para. 3.16.1: "En vista de que la suspensión de una pena de prisión significa que el acusado no pase tiempo encarcelado, deseo aconsejarle que esta sería manifiestamente inadecuada en el caso de quienes parecen ser los máximos responsables por la comisión de crímenes de guerra y comisión de lesa humanidad. Una decisión de suspender las penas de cárcel de estas personas podría sugerir que los procesos se llevaran a cabo, o bien con el propósito de sustraer a las personas de que se trate de su responsabilidad penal, de conformidad con los artículos $17(2)($ a) y $20(3)$ (a) o alternativamente que los procesos hayan sido instruidos de manera que, dadas las circunstancias, fueren incompatibles con la intención de someter a las personas a la acción de la justicia, conforme a lo establecido en los artículos $17(2)(c) y$ $20(3)(b)$. 
conference in Colombia that in contexts of negotiated transitions alternative sentences could be applied. In this case, the complementarity test must consider, among other elements, "the type and degree of restrictions on liberty."199

Hence, even though the 2015 Deputy Prosecutor's position is softer than the 2013 Prosecutor's letter, both reflect that, in their opinion, an effective sanction is required by the ICC Statute, even mediating a peace negotiation. And, while for the Deputy Prosecutor prison time is not an indispensable punishment in transitional contexts, effective restrictions on liberty must be applied. As a result, those elements would mean that conditional amnesties, even if submitted to their recipients' contribution to truth and reparation, are no longer enough to satisfy the duty to prosecute international crimes.

In summary, according to the elements discussed above, rather than conditional amnesties current ICL would only admit alternative sanctions, conditioned on offenders contributing to truth, reparation, and reconciliation in transitional contexts. ${ }^{200}$ Additionally, even if those sanctions assume a restorative approach, they would necessarily imply a restriction of liberty. And, to do so, a judicial process is required. In other words, regarding serious international crimes the practice of conditional amnesties generally granted through truth commissions would no longer be possible. A judicial process would be needed, in which a sentence is pronounced establishing restrictions on liberty - though not necessarily prison-in addition to restorative measures. This approach was adopted in Colombia, as the following item shows.

\subsection{The Colombian Approach: A Negotiated System of Criminal Justice}

During the late 1980s and early 199os Colombia held peace negotiations with guerrilla groups who accepted demobilization in exchange for amnesties and political participation. ${ }^{201}$ At that time, as the general practice around the

199 James Stewart, Deputy ICc Prosecutor, 'Transitional Justice in Colombia and the Role of the International Criminal Court,' 13 May 2015, 13, https://www.icc-cpi.int/iccdocs/otp/ otp-stat-13-05-2015-ENG.pdf (accessed on 8 February 2018).

200 See on alternative sanctions Roht-Arriaza, 'After Amnesties Are Gone: Latin American National Courts and the New Contours of the Fight against Impunity', 344; Louise Mallinder, 'The End of Amnesty or Regional Overreach? Interpreting the Erosion of South America's Amnesty Laws,' International and Comparative Law Quarterly 65, no. 3 (2016): 649 .

201 To have a look into these processes, see Marc Chernick, 'Negotiating Peace amid Multiple Forms of Violence: The Protracted Search for a Settlement to the Armed Conflicts in Colombia,' in Comparative Peace Processes in Latin America, ed. Cynthia Arnson (Stanford: Stanford University Press, 1999), 159-99. 
world, amnesties were unconditional, regardless of the nature or scope of the crimes committed by their beneficiaries.

A new demobilization process with paramilitary groups occurred in 2003 . By then, Colombia was already part of the ICc Statute, which, in combination with a consistent Inter-American jurisprudence against impunity, put pressure on the government to ensure higher criminal accountability. As a result, the 2005 Peace and Justice Law was adopted establishing a system of criminal responsibility with lenient prison sanctions in exchange for contributing to peace.

During the 2012-2016 peace negotiations between the government and the FARC guerrilla, the discussion on criminal justice was a complex matter. The ICL framework, the Inter-American jurisprudence on human rights, the precedent of the Justice and Peace Law, the political character of the guerrilla, and the active role played by the Office of the ICC Prosecutor and by national and international NGOS, led to an unprecedented and sophisticated system of criminal justice, set as a part of a comprehensive framework for truth, justice, and reparation.

This item will present a general overview into the precedent of the Justice and Peace Law, and then it will present the system of criminal justice set up by the 2016 Peace Agreement.

\subsubsection{The Precedent of the Justice and Peace Law}

Unlike the political character of the negotiations with the guerrilla in Colombia, the process involving paramilitary groups between 2003 and 2005 was basically a deal for demobilization in exchange for judicial and socio-economic benefits. ${ }^{202}$ There was no discussion on the causes of conflict, or political, economic, and social reforms. At that time, the government in office did not even recognize the existence of an armed conflict in Colombia but just a terrorist threat against the State. ${ }^{203}$

Designing a legal framework for this process, in August 2003 the government presented to the Congress a law project on alternative penalties. ${ }^{204}$ It

\footnotetext{
202 Alto Comisionado para la Paz, Acuerdo de Santa Fe de Ralito para Contribuir a la Paz de Colombia, 15 July 2003, http://www.altocomisionadoparalapaz.gov.co/acuerdos/ acuerdos_t/jul_15_03.htm, accessed on 20 April 2017.

203 Hernando Salazar, "Colombia decide si reconoce la existencia de un conflicto armado," BBC Mundo, (11 May 2011), available at: http://www.bbc.com/mundo/noticias/2011/05/110511_ colombia_impliaciones_reconocimiento_conflicto_armado_jrg (accessed on 6 August 2017).

204 Congreso de la República de Colombia, Gaceta Oficial, Proyecto de Ley Estatutaria 85 de 2003 Senado, accessed on 3 March 2017.
} 
was not the outcome of a negotiation among the parties - the government and the paramilitaries-but an instrument proposed by the government to facilitate demobilization. The project established the conditional suspension of penalties to members of armed groups participating in peace talks by the discretional decision of the President of the Republic, on the condition of contributing to victims' reparation and informing changes of residence. There was no real mechanism of accountability but an incentive for demobilization. In Saffon and Uprimny's words, the project "consisted in a concession of legal pardons to all armed actors who accepted to demobilize, and was based on the restorative idea that criminal punishment did not contribute and could even become an obstacle for achieving reconciliation."205

Said project was largely criticized by human rights national and international organizations, which denounced it as an impunity bill. ${ }^{206}$ As a result, the government withdrew the project from Congress. ${ }^{207}$

A new initiative was promoted by some congresspeople gathering views from academia, victims, and human rights sectors. ${ }^{208}$ The new called Justice and Peace Law project "passed from one of absolute rejection of criminal punishment and total silence on victim's rights to an admission of the importance of achieving equilibrium between peace needs and justice requirements."209 This law was approved in $2005,{ }^{210}$ and later passed the Constitutional Court's control, which balanced the law with constitutional and international standards. ${ }^{211}$

The Law created a system of criminal trial for demobilized not eligible for amnesty. The process included investigation, trial, and sentences according to ordinary criminal law, with penalties that could amount up to 6o years in prison. But because of the accused's contribution to peace, the sentence included an alternative punishment of prison between a minimum of 5 and a

205 Saffon and Uprimny, 'Uses and Abuses of Transitional Justice in Colombia,' 366.

206 For a comprehensive analysis on the project of alternative penalties and the main legal critics to it, see Catalina Botero, La Ley de Alternatividad Penal y Justicia Transicional (Bogota: DeJusticia, 2004).

207 Verdad Abierta, Procesos de Justicia y Paz, https://verdadabierta.com/la-historia/ periodo4/justicia-y-paz (accessed on 10 February 2016).

208 Pablo Kalmanovitz, 'Introduction: Law and Politics in the Colombian Negotiations with Paramilitary Groups,' in Law in Peace Negotiations, ed. Morten Bergsmo and Pablo Kalmanovitz (Oslo: Torkel Opsahl Academic EPublisher, 2010), 4-5.

209 Saffon and Uprimny, 'Uses and Abuses of Transitional Justice in Colombia,' 366.

210 Congreso de la República de Colombia, 'Ley 975 (Ley de Justicia y Paz)' (2005).

211 Corte Constitucional de Colombia, Sentencia C-370/o6 (18 May 2006). 
maximum of 8 years in prison. ${ }^{212}$ Thus, instead of conditional amnesties, the Law created a system of conditional reduced penalties.

From a total of 24.640 people demobilized under the process, 3.666 were submitted to this Law. At the end of 2015 more than 50.000 crimes had been admitted, but only 33 sentences had been pronounced in 10 years. ${ }^{213}$ However, beyond the practical difficulties during the implementation of the Law, scholars generally admit that the system of conditional reduced penalties meets international standards on justice. Burbidge says that the rule of $5^{-8}$ years of prison seems balanced, as excessive sentences or excessive leniency could affect the intention of the perpetrators to continue in the negotiation in one side, and in the other make peace fragile. He also considers that the fact that the Law was approved by the Congress, controlled by the Constitutional Court, and the accused were judged and punished in due form, regardless of the duration of the sentence, makes an ICC intervention unlikely. ${ }^{214}$ On this point, Ambos argues that the requirements of the complementarity test set by Article 17 of the ICC Statute were met, since the mitigation of punishment did not preclude neither an investigation nor a prosecution. ${ }^{215}$

This law set up a high standard of criminal accountability in Colombia, owing to the relevant international legal norms and discourses brought to the discussion by different actors. However, even if expected by most people, it was not possible to apply the same system to the guerrilla. As noted, the paramilitary groups demobilized under a framework of submission to justice in exchange for benefits. On the contrary, the guerrilla wanted a political deal, addressing the root causes of conflict, in which they defended the justness of their fight. As such, a new mechanism was necessary.

\subsubsection{The Special Jurisdiction for Peace}

In 2012 the Government and the FARC agreed on a negotiation agenda, in which no reference to justice or accountability was included. In item 3.3 the agenda said that the government would review the situation of members of the guerrilla detained or sentenced, and in item 4 the parties agreed to discuss the rights of victims. ${ }^{216}$ Moreover, the guerrilla leaders openly rejected

\footnotetext{
212 Congreso de la República de Colombia, Ley 975 (Ley de Justicia y Paz), 2005 Article 29.

213 Verdad Abierta, ‘¿Qué Nos Dejan 10 Años de Justicia y Paz?,' Verdad Abierta, 2015, http:// www.verdadabierta.com/especiales-v/2015/justicia-paz-1o/ (accessed on 1 April 2018).

214 Peter Burbidge, 'Justice and Peace?-The Role of Law in Resolving Colombia's Civil Conflict,' International Criminal Law Review 8, no. 3 (2008): 576.

215 Ambos, 'The Legal Framework of Transitional Justice,' 8o.

216 Gobierno de Colombia and Farc, 'Acuerdo General Para La Terminación Del Conflicto y La Construcción de Una Paz Estable y Duradera.'
} 
any notion of individual responsibility. They claimed collective responsibility, and that if any form of justice had to be applied it should be social justice. ${ }^{217}$ However, the guerrilla's position on this matter profoundly changed during the negotiation process. And it happened because of their understanding of applicable international standards, a task in which different national and international actors played a crucial role. ${ }^{218}$

As the guerrilla wanted an agreement grounded on international law, and even to be considered as an international legal accord, they finally understood that its content had to be substantially consistent with international legal standards. On this point, several elements and actors draw attention to relevant legal norms. First, the precedent of the Justice and Peace Law set up a high standard on criminal responsibility which was difficult to lower. Second, as noted above, the Office of the ICc Prosecutor actively reminded Colombia of its obligations under the ICC Statute to pursue international crimes. This pressure was reinforced by the fact that the Prosecutor has kept Colombia under preliminary examination since 2004. ${ }^{219}$ Third, the participation of a UN Secretary-General's Special Representative during the negotiations should have brought to the table the UN position regarding the impossibility to grant amnesties for serious crimes, even in peace processes. ${ }^{220}$ Forth, several human rights organizations widely insisted on the obligation to ensure victims' rights to truth, justice, and reparation.

As such, the Final Agreement developed a Comprehensive System of Truth, Justice, Reparation, and Non-Repetition, within its chapter on victims. ${ }^{221}$ Regarding justice, a Special Jurisdiction for Peace was created. For that, the Agreement declared that according to international law, states emerging from armed conflict have the autonomy to adopt the mechanisms of justice that respond to the complexities of the context, provided that they respect international human rights parameters. ${ }^{22}$ Then, the Agreement affirmed that the Special Jurisdiction for Peace was inspired by a restorative justice approach. ${ }^{223}$

217 Nelson Camilo Sanchez, 'Could the Colombian Peace Accord Trigger an ICC Investigation on Colombia?', American Journal of International Law 110 AJIL Unbound Symposium on the Colombian Peace Talks and International Law (2016): 110.

218 A detailed analysis on the actors and discourses bringing international law elements to the peace process and its agreement will be offered in Chapter 3 .

219 The Office of the Prosecutor, 'Report on Preliminary Examination Activities 2016' (The Hague: International Criminal Court, 2016), para. 231.

220 UN Secretary-General, 'Report of the Secretary-General on the Rule of Law and Transitional Justice in Conflict and Post-Conflict Societies,' para. 64.

221 Government of Colombia and Farc, 'Final Agreement to End the Armed Conflict and Build a Stable and Lasting Peace,' 132.

222 Government of Colombia and FARC, 144.

223 Government of Colombia and FARC, 144. 
Defining the content and scope of the Special Jurisdiction, the Agreement invoked international law as the jurisdiction's main framework of reference. ${ }^{224}$ The deal established that for the qualification and treatment of crimes under this jurisdiction, in addition to the Colombian Criminal Code, judges must consider the applicable norms of IHRL, IHL, and ICL. ${ }^{225}$ As such, the Agreement invokes article 6(5) of Additional Protocol II restraining its application to conducts for which international law does not prohibit amnesty; ${ }^{226}$ and following this line, the Agreement excluded from amnesty conducts defined as international crimes by the ICC Statute. 227

The Special Jurisdiction for Peace has competence over guerrilla members, state agents, and civilians who directly or indirectly participated in the commission of crimes related to armed conflict. ${ }^{228}$ Regarding sanctions when amnesty is not possible, the Tribunal can define different types of punishments, according to the accused's admission of truth and responsibility. Only those who fully cooperate with the process, provide truth and acknowledge responsibility, will receive restorative sanctions-e.g. working in demining, substitution of crops of illicit use, and construction of public infrastructure-accompanied by restrictions on liberty of movement and residence for a period of 2 to 8 years, depending on their level of responsibility. Those who do not provide the truth or accept responsibility, and are found guilty, will receive prison sentences.

This model of criminal accountability is the result of adapting to the context international legal norms, legal discourses, and related practices relevant to amnesty and criminal responsibility under international law. As seen in the Colombian case, no specific formula was taken as such from international law, but a particular model was designed interpreting and applying to the context the myriad of legal elements brought to the negotiations by several actors and considering the previous mechanisms of transitional justice adopted in the country. The frame in which such a normative process happens is jus post bellum.

224 The Special Jurisdiction for Peace's statutory law states that its main framework of reference is given by IHRL and IHL. Cfr. Congreso de la República de Colombia, Ley 1957 de 2019, Art. 23: “[...] los marcos jurídicos de referencia incluyen principalmente el Derecho Internacional en materia de Derechos Humanos (DIDH) y el Derecho Internacional Humanitario (DIH)."

225 Government of Colombia and FARC, 147.

226 Government of Colombia and FARC, 148, 15 .

227 Government of Colombia and FARC, 151.

228 A ruling of the Constitutional Court said later that civilians could be investigated and tried by this Special Jurisdiction only if they voluntarily decide so. Corte Constitucional, Sentencia C-674-17 (2017). 


\section{Reparations for Victims}

Reparation for victims is a critical component of transition from armed conflict to peace. At least two reasons explain the relevance of reparations in transition. First, the growing development of I H RL has provided a clear framework on reparations for serious violations of human rights, applicable to contexts of armed conflict. Second, the shift from a retributive to a restorative approach to justice in transitions to peace enhanced the role of reparations. While a retributive approach to transition is mainly rooted in the punishment of the offender, a restorative approach focuses on the redress of victims. ${ }^{229}$

Colombia has made significant efforts to provide reparations for victims of armed conflict, even without any peace process ongoing. Before the 20122016 peace talks with the FARC, the government promoted, and the Congress adopted, the 2011 Law on Victims and Land Restitution, which is considered the most developed system of reparations ever conceived in the world. ${ }^{230}$ Now, the 2016 Peace Agreement adopted a Comprehensive System of Truth, Justice, and Reparations, which incorporates the 2011 Law on Victims. ${ }^{231}$ Both instruments are largely and explicitly based on international law.

In this way, this section is aimed at analyzing the role of international law regarding the development of a system of reparations for transition in Colombia. To this purpose, the section is divided into two parts. First, it presents the international legal framework on reparations for victims of armed conflict. Second, it discusses the Colombian system of reparations, and how it incorporates international standards notwithstanding the challenge of repairing several millions of victims.

\subsection{Legal Framework on Reparations for Victims of Armed Conflict}

This item presents the international legal framework on reparations, showing how reparations became an internationally-protected right for victims of violations of human rights and IHL, even in the context of damages occurred during armed conflict.

229 Ilaria Bottigliero, Redress for Victims of Crimes under International Law (Leiden: Nijhoff, 2004), 34 .

230 Unidad de Atención y Reparación a Víctimas, Universidad de Harvard destaca Política Integral de Reparación de Víctimas en Colombia, 2015, available at: http://www .unidadvictimas.gov.co/es/valoraci\% $\mathrm{C}_{3} \% \mathrm{~B} 3 n$-y-registro/universidad-de-harvard -destaca-pol\% $\mathrm{C}_{3} \%$ ADtica-integral-de-reparaci $\% \mathrm{C}_{3} \% \mathrm{~B} 3 n-\mathrm{de}-\mathrm{v} \% \mathrm{C}_{3} \% \mathrm{ADctimas}-\mathrm{en}$.

231 Government of Colombia and FARC, 'Final Agreement to End the Armed Conflict and Build a Stable and Lasting Peace,' 132. 


\subsubsection{The Right to Reparation in International Law}

Since its paradigmatic decision in the Chorzów Case, the former Permanent Court of International Justice stated in 1927 that: "It is a principle of international law and even a general conception of law that any breach of an engagement involves an obligation to make reparation in an adequate form [...] Reparation is the indispensable complement of a failure to apply a convention and there is no necessity for this to be stated in the convention itself." 232

This notion of reparation was basically referred to restitution and compensation and was historically seen as an inter-state measure. ${ }^{233}$ However, the progressive development of IHRL extraordinarily expanded the scope of reparations and brought individuals to the international legal arena as subjects of reparation. Most international human rights treaties include reparation as a fundamental element of the state's obligation to guarantee human rights. Article 8 of the Universal Declaration of Human Rights enshrines the individual right to an effective remedy for any act violating the rights of the people. ${ }^{234}$ This provision was translated into a binding instrument through the ICCPR, ${ }^{235}$ whose Article 2(3) establishes the right to an effective remedy, which has been interpreted by the Human Rights Committee as involving reparation. ${ }^{236}$ It has been similarly enshrined in Article 2(1) of the ICESCR, ${ }^{237}$ Article 6 of the International Convention on the Elimination of All Forms of Racial Discrimination (ICERD), ${ }^{238}$ Article 2(c) of the Convention on the Elimination of All Forms of Discrimination against Women, ${ }^{239}$ Article 14 of the Convention against Torture and Other

232 Factory at Chorzów Case (Germany v. Poland), Jurisdiction, 1927, PCiJ, Ser. A, No. 9, p. 21.

233 Christine Evans, The Right to Reparation in International Law for Victims of Armed Conflict (Cambridge: Cambridge University Press, 2012), 29.

234 'Universal Declaration of Human Rights,' Pub. L. No. UN Doc. A/81o (1948).

235 International Covenant on Civil and Political Rights.

236 Human Rights Committee, General Comment No. 31, The Nature of General Legal Obligation Imposed on States Parties to the Covenant, CCPR/C/21/Rev.1/Add.13, 2004, para. 16.

237 International Covenant on Economic, Social and Cultural Rights. This Article does not proclaim expressly the right to a remedy in case of violation of the rights enshrined in the Covenant, but only calls states to adopt the measures to grant these rights. Nonetheless, the Committee on Economic, Social and Cultural Rights has interpreted that "[a]mong the measures which might be considered appropriate, in addition to legislation, is the provision of judicial remedies with respect to rights which may, in accordance with the national legal system, be considered justiciable." Committee on Economic, Social and Cultural Rights, General Comment No. 3: The nature of States parties' obligations (Art. 2, par.1) (14 December 1900) UN Doc. E/1991/23.

238 'International Convention on the Elimination of All Forms of Racial Discrimination,' Pub. L. No. General Assembly Resolution 2106 (xx) (1965).

239 'International Convention on the Elimination of All Forms of Discrimination against Women,' Pub. L. No. General Assembly Resolution 34/180 (1979). 
Cruel, Inhuman or Degrading Treatment or Punishment, ${ }^{240}$ Articles 15(2) and 16(4-5) of the International Labor Organization (ILO) Convention $169,{ }^{241}$ Article 13 of the European Convention on Human Rights, ${ }^{242}$ Articles 25 and 63 of the American Convention on Human Rights (AmCHR), ${ }^{243}$ and Articles 7, 21, and 26 of the African Charter on Human Rights. ${ }^{244}$

Following such norms, the obligation to provide individual reparation for the violation of human rights has been consistently reaffirmed by different international courts and human rights bodies. ${ }^{245}$ The aim behind this duty is related to the state's positive obligations regarding human rights. The violation of a human right entails the state's responsibility towards the individual, because of the state's obligation to respect, to prevent, and to ensure the rights of all people under its jurisdiction, including a remedy when respect and prevention have failed.

Based on human rights treaties and international practice, the UN General Assembly adopted the Basic Principles and Guidelines on the Right to a Remedy and Reparation for Victims of Gross Violations of International Human Rights Law and Serious Violations of International Humanitarian Law, ${ }^{246}$ which identified the existing legal obligations in the matter. ${ }^{247}$ According to these Basic

240 Convention against Torture and Other Cruel, Inhuman or Degrading Treatment or Punishment.

241 'Convention Concerning Indigenous and Tribal Peoples in Independent Countries C169,' $\S$ General Conference of the International Labour Organization (1989).

242 European Convention for the Protection of Human Rights and Fundamental Freedoms.

243 American Convention on Human Rights.

244 'African Charter on Human and Peoples' Rights' (1981).

245 See generally, European Court of Human Rights, Case of Akkusv. Turkey, Judgment of 9 July 1997; Case of Kurt v. Turkey (Merits and Just Satisfaction), Judgment of 25 May 1998; Case of Doğan and others v. Turkey (Merits and Just Satisfaction), Judgment of 29 June 2004. In the Inter-American Court of Human Rights, see Case of Aloeboetoe et al.v. Suriname (Reparations and Costs), Judgment of September 10, 1993; Case of the Mayagna (Sumo) Awas Tingni Communityv. Nicaragua (Merits, Reparations and Costs), Judgment of August 31, 2001; Case of the Moiwana Community v. Suriname (Preliminary Objections, Merits, Reparations and Costs), Judgment of June 15, 2005; Case of Yatama v. Nicaragua (Preliminary Objections, Merits, Reparations and Costs), Judgment of Jun 23, 2005; Case of the "Mapiripán Massacre" v. Colombia (Merits, Reparations, and Costs), Judgment of September 15, 2005; Case of the Yakye Axa Indigenous Community v. Paraguay (Interpretation of the Judgment of Merits, Reparations and Costs), Judgment of Feb 6, 2006.

246 UN General Assembly, Basic Principles and Guidelines on the Right to a Remedy and Reparation for Victims of Gross Violations of International Human Rights Law and Serious Violations of International Humanitarian Law.

247 In their Preamble, the Basic Principles and Guidelines stress that they "do not entail new international or domestic legal obligations but identify mechanisms, modalities, procedures and methods for the implementation of existing legal obligations under international human rights law and international humanitarian law which are complementary though different as to their norms". UN General Assembly. It is also important to mention 
Principles: "victims are persons who individually or collectively suffered harm $[\ldots]$, through acts or omissions that constitute gross violations of international human rights law, or serious violations of international humanitarian law."248 Additionally, said Principles state that: "A person shall be considered a victim regardless of whether the perpetrator of the violation is identified." 249 The Basic Principles also derivate the right to reparation redressing the harm suffered by victims, from the general obligation to provide an effective remedy for violations of international law. Then, the Principles define reparation as composed by five elements: restitution, seeking to restore the victim to the original situation whenever possible; ${ }^{250}$ compensation, through an economic assessment of the damage; ${ }^{251}$ rehabilitation, including medical and psychological care as well as legal and social services; ${ }^{252}$ satisfaction, aimed at restoring the dignity of victims through measures such as public apologies, truth disclosure, search of missing persons, etc.; ${ }^{253}$ and guarantees of non-repetition, to prevent new violations. ${ }^{254}$

This comprehensive definition of reparation, developed through interpretation and application of different IHRL instruments, was enshrined in a legally binding instrument in the 2007 Convention for the Protection of All Persons from Enforced Disappearance. ${ }^{255}$ Under IHL, the obligation to provide reparations has been considered a customary rule both in international and non-international armed conflicts. ${ }^{256}$ The ICC Statute also provided that the Court "shall establish principles relating to reparations to, or in respect of, victims, including restitution, compensation, and rehabilitation." 257

As such, based on the recognition of the right to reparation under different branches of international law, some authors have even argued the customary

the 2001 Draft Articles on Responsibility of States for Internationally Wrongful Acts, adopted by the ILC, which embodied the obligation to reparation and its modalities and conditions (see Articles $30-31$ and 34-36).

248 UN General Assembly, para. 8.

249 UN General Assembly, para. 9.

250 UN General Assembly, para. 19.

251 UN General Assembly, para. 20.

252 UN General Assembly, para. 21.

253 UN General Assembly, para. 22.

254 UN General Assembly, para. 23.

255 International Convention for the Protection of All Persons from Enforced Disappearance Art. 24 .

256 Henckaerts and Doswald-Beck, Customary International Humanitarian Law. Volume I: Rules, Rule 15 o.

257 'Rome Statute of the International Criminal Court' (1998) Art. 75. 
character of reparations. For Evans, because of the "extensive recognition of the right of the individual to reparation in human rights and humanitarian law, as well as under general international law, it appears reasonable to state that this right has acquired a degree of recognition as forming part of customary law."258

4.1.2

Reparations for Armed Conflict-related Violations of Human Rights and IHL

International human rights norms on reparation were primarily conceived to address individual violations of rights on a case-by-case basis. ${ }^{259}$ As noted by Carrillo, "they simply are not configured to deal with gross and systematic violations in the same way." 260 This is a major challenge faced by reparations in contexts of massive violations of human rights and IHL, such as during armed conflict. No state jurisdiction or international system would have the capacity to redress all the victims of armed conflict-related human rights violations under a judicial mechanism for reparation.

There are several factors involved when defining the mechanisms of redress for victims of armed conflict. One could mention the number of victims, their proportion within the total population, the economic situation of the country, the priority given to other transitional justice measures, among other factors. Additionally, the fact of having different actors involved in the conflict, where at least one is a non-state actor, poses challenges as who is responsible for reparations.

Regarding that point, the obligation to pay reparations has been traditionally assigned to the state. Nevertheless, the current development of ICL raised the responsibility of individuals for repairing the damages caused to their victims. It means that non-state armed actors in a NIAC should also pay reparations. The Basic Principles on Reparations establish that a state shall provide reparation to victims for acts or omissions which can be attributed to it, and that when a non-state actor is liable for reparation, such party should repair the victim or compensate the state if the state has already done it. But, again, the Basic Principles conclude that: "States should endeavour to establish national programmes for reparation and other assistance to victims in the

258 Evans, The Right to Reparation in International Law for Victims of Armed Conflict, 39.

259 Pablo De Greiff, 'Justice and Reparations,' in The Handbook of Reparations, ed. Pablo De Greiff (Oxford: Oxford University Press, 2006), 454.

26o Arturo Carrillo, 'Justice in Context: The Relevance of the Inter-American Human Rights Law and Practice to Repairing the Past,' in The Handbook of Reparations, ed. Pablo de Greiff (Oxford: Oxford University Press, 2006), 527. 
event that the parties liable for the harm suffered are unable or unwilling to meet their obligations."261

On this point, the Inter-American Court of Human Rights declared, in the case Mapiripan Massacre v. Colombia, that the State was obligated to provide reparation, even if the massacre was committed by a non-state actor. This conclusion was based on the State's lack of due diligence to prevent the massacre, which was its positive obligation according to the AmCHR. ${ }^{262}$

Considering these particularities on reparation for victims of armed conflict, the Association of International Law adopted in 2010 a Declaration of International Law Principles on Reparation for Victims of Armed Conflict. ${ }^{263}$ This document provides general guidelines on the matter, defining the holder of the right to reparation, its content, and the parties responsible to pay reparations. ${ }^{264}$ On its Commentary to the Declaration, the Association stresses that the legal protection provided by international law to victims of human rights violations and breaches to IHL should not be reduced in contexts of armed conflict. However, the Association admitted that in case of massive violations of rights the conditions and amounts of reparations must regard the capacities of the liable state in post-conflict scenarios. ${ }^{265}$ Later, in 2014 the Association adopted a Draft on Procedural Principles for Reparation Mechanisms ${ }^{266}$ devoted to the access to effective redress mechanisms.

According to the elements discussed above, the victim's right to reparation must be ensured even when such a right emerges from violations caused within an armed conflict. However, the judicial approach to justice and reparation for individual violations of human rights is not feasible in cases of massive violations of human rights occurred during and armed conflict. In such contexts, systems of reparations must be designed in a way in which international standards are observed, at the time that reparations play a role in a broader

261 UN General Assembly, Basic Principles and Guidelines on the Right to a Remedy and Reparation for Victims of Gross Violations of International Human Rights Law and Serious Violations of International Humanitarian Law, paras 15-16.

262 Inter-American Court of Human Rights, Case of 'Mapiripán Massacre' v. Colombia, Judgment of 15 September 2005 (2005).

263 International Law Association, 'Draft Declaration of International Law Principles on Reparation for Victims of Armed Conflict' (2010).

264 International Law Association Article 5.

265 See Commentary on Article 5. International Law Association.

266 International Law Association, 'Draft Procedural Principles For Reparation Mechanisms' (2014). 
political agenda, serving as a form of recognition to victims and helping to restore civic trust and reconciliation. ${ }^{267}$

\subsection{Colombian Approach to Reparations}

The international legal framework on reparations presented above has been developed in different ways in Colombia. From judicial to administrative systems of reparation, Colombia has assumed reparations as a victim's rights that must be addressed, regardless of a peace agreement. Since 1997, Colombia set up a program for administrative reparation addressed to victims of terrorism and other facts related to armed conflict. ${ }^{268}$ In 2005 a judicial approach to reparation was incorporated into the Justice and Peace Law, which was later complemented with a norm on administrative reparations. Finally, a comprehensive system of reparations was implemented before the 2012-2016 peace negotiations, which could be even considered as an element facilitating the process and the participation of victims in those negotiations. As such, three dimensions of reparation for victims of armed conflict in Colombia must be considered as follows.

\subsubsection{Judicial Reparation: Justice and Peace Law}

As presented above in the section on criminal justice, in 2005 Colombia adopted the Justice and Peace Law for the demobilization of paramilitary groups. This instrument created a special system of criminal responsibility, granting reduced penalties in exchange for cooperation with justice and reparation to victims. According to Article 2 of this Law, all the system had to be interpreted and applied according to the Colombian Constitution and to international treaties duly ratified by Colombia.

Regarding reparations, the Law established a judicial mechanism of reparation in which reparation was addressed only to victims whose perpetrators were submitted to this judicial system. A Reparations Fund was created, composed by the illegally obtained assets delivered by the demobilized and limiting victim's reparation to the budget of the Fund. However, the Constitutional Court introduced two important changes on this point. First, it said that both legal and illegally obtained assets should be available for the reparation of victims. ${ }^{269}$ Second, the Court ruled that no

267 De Greiff, 'Justice and Reparations,' 454.

268 Congreso de la República de Colombia, 'Ley 418' (1997).

269 Corte Constitucional de Colombia, Sentencia C-37o/o6, paragraph 6.2.4.1.11. 
budgetary constraint could be used as a State's excuse for giving reparation to a victim. ${ }^{270}$

Nevertheless, such a system of judicial reparation was insufficient for redressing millions of victims affected by armed conflict. Only victims recognized within a criminal procedure were beneficiaries of reparation and it was to the judge to define forms and amounts on a case-by-case basis. For that reason, a program of administrative reparation was later created in $2008,{ }^{271}$ aimed at repairing victims beyond the criminal process through an administrative procedure. The new program allowed more victims to receive reparations. However, although the system predicated comprehensive reparation, it was focused on compensation.

4.2.2 Comprehensive Administrative Reparations: Law on Victims and Land Restitution

In 2011, with the presence of the UN Secretary-General, Colombia adopted an unprecedented Law on Victims and Land Restitution. ${ }^{272}$ The Law established a comprehensive system of administrative reparation addressed to all the victims of armed conflict since 1985, which integrated the previous systems. The Law was largely inspired by international law. Its Article 3 defines victims as people who individually or collectively have suffered damage as a consequence of a violation of IHL or IHRL within the armed conflict.

Article 25 defines reparation in the same terms as the UN Basic Principles on Reparations. As such, the Law establishes measures of restitution, compensation, rehabilitation, satisfaction, and guarantees of non-repetition, entirely assumed by the State. To that purpose, the Law created a unified register of victims integrating existing registers and programs of reparation. Up to 1 April 2019, 8.803.836 victims were registered. ${ }^{273}$ Additionally, a Unit for the Attention and Reparations of Victims was created, tasked to coordinate the implementation of the Law.

In 2014 the Carr Center for Human Rights Policy at the Harvard Kennedy School compared this system of reparation with other 31 mechanisms adopted

270 Corte Constitucional de Colombia, paragraph 6.2.4.3.3.2. For an analysis on this point in the Colombian case, see Julian Guerrero and Mariana Goetz, 'Reparations for Victims in Colombia: Colombia's Law on Justice and Peace,' in Reparations for Victims of Genocide, War Crimes and Crimes against Humanity: Systems in Place and Systems in the Making, ed. Carla Ferstman, Mariana Goetz, and Alan Stephens (Leiden: Martinus Nijhoff, 2009), 435-58.

271 Gobierno de Colombia, Decreto 1290 (2008).

272 Congreso de la República de Colombia, Ley 1448 (Ley de Víctimas y Restitución de Tierras).

273 Registro Único de Víctimas, https://www.unidadvictimas.gov.co/es/registro-unico-devictimas-ruv/37394 (accessed on 1 April 2019). 
around the world since 1979. ${ }^{274}$ The study concluded that the Colombian system is the most complete ever adopted for reparation of victims of armed conflict in the world, though the Center warned on the challenges to implement it, considering the high number of victims. ${ }^{275}$

\subsubsection{Reparations in the 2016 Peace Agreement}

Since its preamble, the Agreement states its victim-centered approach and the importance given to the right to reparation, according to international law. ${ }^{276}$ There is a chapter on victims, in which a system of truth, justice, and reparation was established. Regarding reparations, the Agreement considers them as a condition for peace, and adopts a comprehensive approach, following international standards on restitution, compensation, rehabilitation, satisfaction, and non-repetition. ${ }^{277}$

The Agreement recognized the existing system of reparations created by the 2011 Law on Victims. Nonetheless, the document proposed to adjust it in a participatory way, and according to the context and opportunities given by the end of armed conflict. Additionally, it stressed on the return of displaced people $^{278}$ and collective reparations, ${ }^{279}$ where former guerilla members should contribute by doing community work, demining, and offering public apologies. ${ }^{280}$ The guerrilla also assumed the obligation to give its assets for the reparation to victims. ${ }^{281}$ On this point, reparation by the guerrilla, as a nonstate actor, will be mainly related to the judicial procedures before the Special Jurisdiction for Peace, which, as part of the sanctions, will impose measures of reparations under a restorative justice approach.

274 Carr Center for Human Rights Policy, 2014. Evaluation for the Unidad para las Victimas: global and comparative benchmarking. Available at http://wp.presidencia.gov. co/Noticias/2014/Octubre/Paginas/20141022_o9-Estudio-de-Harvard-concluye-queColombia-lider-en-reparacion-victimas-revela-el-PresidenteSanto.aspx (accessed 20 November 2015).

275 The number of victims of armed conflict in Colombia represents around $18 \%$ of the total population of the country, which up to May 2019 was estimated in 48.2 million people. Source: http://www.dane.gov.co/index.php/estadisticas-por-tema/demografia-ypoblacion/censo-nacional-de-poblacion-y-vivenda-2018/cuantos-somos/ (accessed on 5 May 2019).

276 Government of Colombia and FARC, 'Final Agreement to End the Armed Conflict and Build a Stable and Lasting Peace,' 2.

277 Government of Colombia and FARC, 129-30.

278 Government of Colombia and FARC, 182.

279 Government of Colombia and FARC, 179.

280 Government of Colombia and FARC, 179 .

281 Government of Colombia and FARC, 186. 
Here, the Agreement adopted the approach of the offender's primary obligation to provide reparation, and the State's subsidiary role when there is no full reparation from the actor who caused the damage. Regarding this approach, the Agreement explicitly invokes the positive obligations of the State under IHRL. ${ }^{282}$ However, on this point, the Colombian approach offers valuable insights on the growing discussion around the role of non-state armed actors regarding reparations in transitions from NIACs. International law is still too general on this matter, but legal basis exists, as seen in the legal framework presented here. Then, practice such as the Colombian would certainly contribute to better understand and apply the obligations of non-state actors on reparations, within and beyond judicial mechanisms.

Here, one can see how international law has framed the debate on reparations for victims of armed conflict in Colombia since 2005. Again, as for criminal responsibility, international law does not provide a specific general formula, but the normative elements that must be addressed to find the appropriate mechanism for a given context. As it will be further analyzed in Chapter 3 , such a normative frame guiding the design of a concrete transitional mechanism is the display of jus post bellum.

\section{Inclusive Transitions}

Contemporary negotiations aimed at ending NIACs are no longer a matter to be decided only by the parties directly confronted. In general, the agreement resulting from a peace negotiation has impacts over different groups, and society at large. Thus, those groups should be heard, and their needs be addressed in a differential way in a peace deal. This inclusiveness is increasingly considered a condition of legitimacy, effectiveness, and sustainability of peace agreements. ${ }^{283}$

There are at least three reasons behind the need for inclusivity in transitions to peace. First, just as armed conflict has differential impacts on certain groups-e.g. women and ethnic communities - peace also does so. Second, transition from armed conflict to peace represents an opportunity to address structural discriminatory situations in society, which are generally at the base of the conflict or are exacerbated by it. Third, since parties in a peace process

282 Government of Colombia and FARC, 147.

283 Jennifer Easterday, "Peace Agreements as a Framework for Jus Post Bellum," in Jus Post Bellum: Mapping the Normative Foundations, ed. Carsten Stahn, Jennifer Easterday, and Jens Iverson (Oxford: Oxford University Press, 2014), 399. 
discuss changes in the political and social order, it represents an opportunity for the incorporation of citizens into the polity, improving their engagement in the post-agreement scenario. ${ }^{284}$

Thus, given the importance of inclusiveness in peace processes, and the role of international law in peacemaking and peacebuilding, this section discusses if there is any normative obligation to hold inclusive transitions. On this matter, Kastner considers that the inclusion of social actors "is not only advisable from a pragmatic conflict resolution perspective; it has rather become part of the normative framework of peace negotiations and [...] is increasingly being internalized as a legal obligation." ${ }^{285}$ Similarly, discussing on jus post bellum, Turner pleads for a principle of inclusivity in peace processes, given the requirements of human rights law regarding differential participation and inclusion of certain groups. ${ }^{286}$

This search for inclusivity has been present in transition from armed conflict to peace in Colombia in different ways. Since the normative framework on internally displaced persons, the Constitutional Court requested State institutions to adopt a differential approach in measures addressed to women, indigenous peoples, and Afro-descendants. Following this precedent, the 2011 Law on Victims incorporated a differential approach to women and ethnic communities. Finally, the 2012-2016 peace process with the FARC guerrilla developed unprecedented inclusive mechanisms, addressing different social groups.

This section analyzes to what extent Colombian practice reflects a legal obligation on inclusive transitions to peace, by associating international normativity related to inclusion and participation of certain social groups. For this purpose, it refers to international law provisions regarding both the general state's obligation to promote participation of people on matters of their interest, and the specific duty to include certain social groups in peace processes and agreements.

The section is divided into two parts. The first part presents the international legal framework to support inclusive peace transitions as a legal obligation, rather than a mere political choice. The second part assesses how Colombia

284 Catherine O'Rourke, 'Transitioning to What? Transitional Justice and Gendered Citizenship in Chile and Colombia,' in Gender in Transitional Justice, ed. Susane BuckleyZistel and Ruth Stanley (Basingstoke: Palgrave Macmillan, 2012), 152; Colleen Murphy and Linda Radzik, 'Jus Post Bellum and Political Reconciliation,' in Jus Post Bellum and Transitional Justice, ed. Larry May and Elizabeth Edenberg (New York: Cambridge University Press, 2013), 317.

285 Kastner, Legal Normativity in the Resolution of Internal Armed Conflict, 147.

286 Turner, "Mapping a Norm of Inclusion in the Jus Post Bellum." 
has implemented its obligations on inclusiveness when defining attention to victims of armed conflict, and the role that participation and the differential approach played in the $2012-2016$ peace process.

\subsection{Legal Framework on Inclusiveness}

International law provides elements to support the demands of certain groups of people to be heard, and their concerns to be included, in peace processes and transitions. The most specific case is the legal regime related to the participation and inclusion of women in peace processes and agreements. However, general provisions are also applicable regarding other social groups, victims, and civil society in general. The following items examine the normative framework regarding these issues.

\subsubsection{On Women and Gender Issues}

Women suffer gender specific impacts because of armed conflict. Armed confrontation intensifies existing inequalities experienced globally by women and they are "specially affected by sexual violence, internal displacement, loss of family members, reinforced gender stereotypes, loss of social position and reduced access to essential supplies and services." 287 However, negotiating peace has been predominantly a male affair. ${ }^{288}$ According to the 2016 Yearbook of Peace Processes, only 10.3\% of people officially participating in peace talks were women. ${ }^{289}$ This reality contradicts both the fact that women are one-half of the population, as well as that their gender-specific experiences and needs resulting from armed conflict are unlikely to be addressed without their participation in peace negotiation processes. ${ }^{290}$

The discussion on the specific impact of armed conflict on women only came to the international arena in the 199os. ${ }^{291}$ In 1992, the Committee

287 Judith Gardam and Michelle Jarvis, Women, Armed Conflict, and International Law (The Hague: Kluwer Law International, 2001), 21.

288 Christine Bell and Catherine O'Rourke, 'Does Feminism Need a Theory of Transitional Justice? An Introductory Essay,' International Journal of Transitional Justice 1, no. 1 (2007): 31. On the historical exclusion and inclusion of women in peace processes, and the potential role of their participation, see Anderlini, Women Building Peace: What They Do, What It Matters.

289 Escola de Cultura de Pau, Yearbook of Peace Processes 2016, ed. Vicenç Fisas (Barcelona: Icaria, 2016), 339 .

290 Bell and O'Rourke, 'Does Feminism Need a Theory of Transitional Justice? An Introductory Essay,' 3 \%.

291 According to Kastner, it was connected with the development of gender-related human rights considerations and the need to respond to gender-based violence. Kastner, Legal Normativity in the Resolution of Internal Armed Conflict, 62. 
on the Elimination of Discrimination against Women adopted General Recommendation 19 related to violence against women. The Recommendation refers to the gender-based risks that women face in contexts of armed conflict and recommends states to take all necessary measures to protect them. ${ }^{292}$ In 1995, the UN Fourth World Conference on Women, Action for Equality Development and Peace stated that "while entire communities suffer the consequences of armed conflict and terrorism, women and girls are particularly affected because of their status in society and their sex." ${ }^{293}$ Then, the Beijing Declaration issued from such a Conference noted that "the equal access and full participation of women in power structures and their full involvement in all efforts for the prevention and resolution of conflicts are essential for the maintenance and promotion of peace and security."294

Following the Beijing Declaration's commitments, the UNSC adopted the crucial Resolution 1325 (2000) on Women, Peace, and Security. This Resolution urges states to increase representation of women at all decisionmaking levels for the prevention, management, and resolution of conflict. ${ }^{295}$ It also requests the Secretary-General to appoint more women as special representatives in peace negotiations, ${ }^{296}$ and to incorporate a gender perspective into peace operations. ${ }^{297}$ Finally, the Resolution calls on all actors involved in peace agreements to adopt a gender perspective. ${ }^{298}$

This resolution introduced a specific international standard on women participation in peace negotiations. According to Ellerby, such a standard is composed by four elements of inclusion: representation (decision-making, quotas), incorporation (gender balance in everyday activities and institutions), protection (safety and equality, gender-based violence, access to resources, anti-discrimination), and recognition (gender perspective, special rights and needs, legal changes). ${ }^{299}$

292 Committee on the Elimination of Discrimination against Women, General Recommendation No. 19 (1992), paras. 16 and 24(t).

293 UN Fourth World Conference on Women, Action for Equality Development and Peace, 'Beijing Declaration and Platform for Action,' Pub. L. No. UN Doc A/Conf.177/2o (1995), para. 135 .

294 UN Fourth World Conference on Women, Action for Equality Development and Peace, 134.

295 UN Security Council, Resolution 1325 (2000), para. 1.

296 UN Security Council, para. 3.

297 UN Security Council, paras $5^{-6 .}$

298 UN Security Council, para. 8.

299 Kara Ellerby, '(En)Gendered Security? Gender Mainstreaming and Women's Inclusion in Peace Processes,' in Gender, Peace and Security: Implementing UN Security Council Resolution 1325, ed. Theodora-Ismene Gizelis and Louise Olsson (Abingdon: Routledge, 2015), 189 . 
For Bell and O'Rourke, Resolution 1325 provides a clear legal basis for addressing the role of women in the negotiation and implementation of peace agreements. For them, even though this resolution was adopted under Chapter VI of the UN Charter, "its legal authority has been accentuated by the fact that it was passed unanimously, and that the resolution uses the language of obligation." ${ }^{300}$ Additionally, subsequent Security Council resolutions have followed and reinforced Resolution 1325's mandates. ${ }^{301}$

This resolution brought to the international practice a growing awareness on women participation and inclusion in peace negotiations and peace agreements. Anderlini notes that despite the difficulties in the implementation of Resolution 1325, "since it was passed, women's demands for inclusion have been heard more often in formal channels." ${ }^{302}$ Bell and O'Rourke have found a "significant increase in references to women in peace agreements after Resolution 1325 was passed." 303 A similar conclusion was reached by Ellerby in 2015.304

In 2005, the Updated Principles to Combat Impunity adopted by the UN Commission on Human Rights ${ }^{305}$ also called for the participation of women, minorities, victims, and civil society in peace processes. Principle 32 asked "to ensure that women and minority groups participate in public consultations aimed at developing, implementing, and assessing reparations programmes." Similarly, Principle 35 affirms that "adequate representation of women and minority groups in public institutions is essential to the achievement" of guarantees of non-repetition.

300 Christine Bell and Catherine O'Rourke, 'Peace Agreements or Pieces of Paper? The Impact of UNSC Resolution 1325 on Peace Processes and Their Agreements,' International and Comparative Law Quarterly 59, no. 4 (2010): 943.

301 See, for example, Resolution 1820 (2008) encouraging all parties in peace talks "to facilitate the equal and full participation of women at decision-making levels" (para. 12); Resolution 1888 (2009) urges that "issues of sexual violence be included in all United Nations-sponsored peace negotiations agendas" (para. 17); Resolution 1889 (2009) pointing out the underrepresentation of women in peace processes, and Resolution 2106 (2013) "reiterates the importance of addressing sexual violence in armed conflict whenever relevant, in mediation efforts, ceasefires and peace agreements" and it request to "engage on sexual violence issues, including with women, civil society, including women's organizations and survivors of sexual violence, and ensure that such concerns are reflected in specific provisions of peace agreements" (para. 12).

302 Anderlini, Women Building Peace: What They Do, What It Matters, 73.

303 Bell and O'Rourke, 'Peace Agreements or Pieces of Paper? The Impact of UNSC Resolution 1325 on Peace Processes and Their Agreements,' 956.

304 Ellerby, '(En)Gendered Security? Gender Mainstreaming and Women's Inclusion in Peace Processes,' 204.

305 UN Commission on Human Rights, "Updated Set of Principles for the Protection and Promotion of Human Rights through Action to Combat Impunity," Pub. L. No. E/CN.4/ 2005/102/Add.1 (2005). 
Finally, the 2008 Nuremberg Declaration on Peace and Justice called for increased representation and active involvement of women in transitional processes. It recommends that "post-conflict legal orders should rectify legal and social discrimination based on gender." 306

\subsubsection{On Ethnic Minorities Issues}

Like women, ethnic minorities can suffer specific impacts by armed conflict because of their ethnicity and their social and cultural conditions. In countries facing NIACs, traditionally marginalized groups could be exposed to higher risks than the rest of the population. Regarding ethnic minorities, armed conflict can cause specific impacts on their culture, their dynamics, their organization, and their territories.

However, unlike the case of women, there is not a specific international legal framework for the participation of ethnic minorities in peace processes, or for their specific needs to be included in peace agreements. Nevertheless, the rights of ethnic minorities have been addressed by several instruments of international law, which could be applied regarding peace processes.

In a general way, the ICERD provides a basis for the integration of racial and ethnic groups to achieve their advancement and full enjoyment of their rights. ${ }^{307}$ Then, the 2001 Durban Declaration recognizes that racial discrimination is among both the root causes and the consequences of armed conflict and calls for the inclusion and participation of traditionally discriminated peoples when deciding matters of their concern. ${ }^{308}$

Regarding indigenous and tribal peoples, the most relevant instrument is the 1989 ILO Convention $169 .{ }^{309}$ According to such an instrument, "the social,

306 UN General Assembly, Nuremberg Declaration on Peace and Justice. Recommendation 2.8.

307 International Convention on the Elimination of All Forms of Racial Discrimination.

308 World Conference against Racism, Racial Discrimination, Xenophobia and Related Intolerance, Declaration, Durban, South Africa, 8 September 2001.

309 General Conference of the International Labour Organisation, 'C169-Indigenous and Tribal Peoples Convention' (1989). According to its Article 1.1: "This Convention applies to:

(a) tribal peoples in independent countries whose social, cultural and economic conditions distinguish them from other sections of the national community, and whose status is regulated wholly or partially by their own customs or traditions or by special laws or regulations;

(b) peoples in independent countries who are regarded as indigenous on account of their descent from the populations which inhabited the country, or a geographical region to which the country belongs, at the time of conquest or colonisation or the establishment of present state boundaries and who, irrespective of their legal status, retain some or all of their own social, economic, cultural and political institutions." 
cultural, religious and spiritual values and practices of these peoples shall be recognised and protected." 310 Additionally, indigenous and tribal peoples must be consulted and have the means to duly participate regarding "legislative or administrative measures which may affect them directly."311 Lastly, the 2007 UN Declaration on Indigenous Peoples included some specific provisions regarding the right to be consulted on measures of relocation and reparations. ${ }^{312}$

\subsubsection{On the Participation of Victims and Civil Society in General}

The participation of victims and civil society actors in peace negotiations is getting increased attention in research and practice. ${ }^{313}$ Since victims suffer the direct impact of armed conflict, they must have a voice, especially regarding the treatment of crimes committed against them and the corresponding reparations. As noted by Ambos, victims' "participation is indispensable to lend legitimacy to this process and make it socially acceptable."314 Similarly, large participation of civil society, either directly — by public consultations or referendums - or through democratically-elected organs is essential to pave the way for national reconciliation. ${ }^{315}$

There is no specific legal basis for the participation of victims and civil society in peace negotiations. However, some general norms provide elements in that sense. General human rights instruments enshrine the right of every person to take part in public affairs (e.g., Article 25(a) of the ICCPR, and Article 23.1(a) of the AmCHR). A peace negotiation, whose outcome will have effects over people other than just the parties in talks, should be considered a public affair. According to Article 68.3 of the ICc Statute, the Court shall permit the views and concerns of the victims "to be presented and considered" at the proceedings. The right of victims to be heard and participate when asking for reparations can be found in the UN Basic Principles on Reparations. ${ }^{316}$ A similar

310 Convention concerning Indigenous and Tribal Peoples in Independent Countries C169 Art. 5 .

311 Convention concerning Indigenous and Tribal Peoples in Independent Countries C169 Art. 6.

312 UN General Assembly, 'United Nations Declaration on the Rights of Indigenous Peoples,' Pub. L. No. Resolution 61/295 (2007). Arts. 10, 28.

313 Thania Paffenholz, 'Civil Society,' in Post-Conflict Peacebuilding: A Lexicon, ed. Vincent Chetail (Oxford: Oxford University Press, 20o9), 64.

314 Ambos, 'The Legal Framework of Transitional Justice,' 40.

315 Ambos, 40; UN Secretary-General, 'Report of the Secretary-General on the Rule of Law and Transitional Justice in Conflict and Post-Conflict Societies,' para. 16.

316 UN General Assembly, Basic Principles and Guidelines on the Right to a Remedy and Reparation for Victims of Gross Violations of International Human Rights Law and Serious Violations of International Humanitarian Law Preamble and Chapter VIII. 
view is found in the Updated Set of Principles to Combat Impunity, providing for the consultation of victims and other sectors of civil society when defining guarantees of non-recurrence of human rights violations. ${ }^{317}$ All those elements were gathered by the 2008 Nuremberg Declaration on Peace and Justice, whose Principle 3 promotes a victim-centered approach in peace negotiations and recommends broader consultations with victims, civil society, and women. ${ }^{318}$

The UN Secretary-General pointed out that inclusivity "increases the legitimacy and national ownership of the peace agreement and its implementation," at the time that it "reduces the likelihood of excluded actors undermining the process." 319 This position is emphasized by Kastner, who sustains that the UN "has manifestly internalized an obligation vis-à-vis the participation of civil society actors in peace negotiations that involves normative considerations and that goes beyond merely reaching out and consulting civil society." ${ }^{320}$

\subsection{The Colombian Approach}

This item presents three mechanisms by which Colombia has assumed and implemented an inclusive and differential perspective in its transition from armed conflict to peace.

\section{$5 \cdot 2.1$}

Differential Approach for the Attention and Reparation of Victims of Armed Conflict

In 1997, Colombia adopted a law on internal displacement, ${ }^{321}$ which included some provisions on the special attention to internally displaced women. However, in 2008 the Constitutional Court found a gender gap in this Law and ordered a series of measures to address the special needs and risks faced by women victims of displacement. The Court referred to international obligations applicable to the matter, with a special emphasis to CEDAW General Recommendation 19 and UNSC Resolution 1325. Under those elements, the Court ordered to different institutions a series of measures to meet the specific needs of displaced women ensuring their participation in the definition and implementation of those actions. ${ }^{322}$

317 UN Commission on Human Rights, Updated Set of Principles for the Protection and Promotion of Human Rights through Action to Combat Impunity. Principle 35 .

318 UN General Assembly, Nuremberg Declaration on Peace and Justice Principle 3 and Recommendation 1.3.

319 UN Secretary-General, 'Strengthening the Role of Mediation in the Peaceful Settlement of Disputes, Conflict Prevention and Resolution,' para. 29.

320 Kastner, Legal Normativity in the Resolution of Internal Armed Conflict, 148.

321 Congreso de la República de Colombia, Ley 387.

322 Corte Constitucional de Colombia, Auto o92/o8 (2008). 
A year later, the same gaps were found regarding indigenous peoples ${ }^{323}$ and Afro-descendants. ${ }^{324}$ For the Court, Colombia was internationally obligated to adopt specific measures regarding the protection of ethnic groups affected by armed conflict. As such, the Court invoked, among other instruments, Article 26 of the ICESCR regarding ethnic minorities and ILO Convention 169.

The Constitutional Court opened a public follow-up system for those decisions, in which the concerned institutions should inform the measures adopted for the differential attention to these groups of victims. ${ }^{325}$ This situation created a positive environment for women and ethnic organizations to promote a public agenda on their specific needs as victims of armed conflict, since they also have the possibility to submit reports to the Court and to participate in their discussion.

These jurisprudential standards were incorporated by the 2011 Law on Victims and Land Restitution. According to this instrument, differential approach regarding gender, ethnicity, sexual orientation, age, and physical conditions is a central principle of the whole system for the attention and reparation of victims. ${ }^{326}$ As such, the Law created a unified register of victims including differential categories. Up to 1 April 2019, from a total of 8.803 .836 victims registered, ${ }^{327}$ 4.218.519 were women, 4.211.087 men, 3.367 LGBTI people, 218.657 indigenous, 776.861 Afro-Colombians, and 41.838 Roma and other ethnic minorities. ${ }^{328}$ To address the conditions of these groups in a differential way, specific norms were adopted regulating special measures regarding ethnic minorities. Additionally, a differential approach subsystem was established to coordinate the adoption of differential measures for victims at all the levels, in which representatives from each population group are present.

$5 \cdot 2.2$

Participation of Victims and Civil Society in the Peace

Negotiations

Armed conflict in Colombia has impacted more than eight million people. It represents around $18 \%$ of the country's total population. ${ }^{329}$ Such an impact

323 Corte Constitucional de Colombia, Auto o04/o9 (2009).

324 Corte Constitucional de Colombia, Auto oo5/o9 (2009).

325 Corte Constitucional de Colombia, Sentencia T-025/04 (2004).

326 Congreso de Colombia, Ley 1448 (2011), Art. 13. Additionally, it is important to mention that the Law explicitly indicates that its provisions must be interpreted and applied according to IHL and IHRL treaties ratified by Colombia (Art. 27).

327 Registro Único de Víctimas, https://www.unidadvictimas.gov.co/es/registro-unico-devictimas-ruv/37394 (accessed on 1 April 2019).

328 Registro Único de Víctimas.

329 The total population of Colombia up to May 2019 was estimated in 48.2 million people. Source: http://www.dane.gov.co/index.php/estadisticas-por-tema/demografia-y-poblacion/ censo-nacional-de-poblacion-y-vivenda-2018/cuantos-somos/ (accessed on 5 May 2019). 
has made armed conflict a constant element in the life of millions of people and their communities. Thus, the participation of victims and civil society in general in the negotiation table and the inclusion of their interests and views in the peace agreement were a must.

The Agreement explicitly states its victim-centered approach. ${ }^{330}$ Additionally, the preceding legal and jurisprudential developments on victims empowered them to claim a significant role in the process. As a result, 60 victims representing different regions, groups, and victimizing facts, participated in the negotiation table in Havana. Moreover, looking for the largest social acceptation of the Agreement, the parties agreed on a mechanism of open participation, in which 3.000 people gave their opinions through UN-led forums around the country, and 17.000 proposals were received through the internet. ${ }^{331}$ These mechanisms and figures express a decisive openness of the parties, and their recognition of victims and civil society's participation as a matter of rights; which is in contrast with the traditional approach to involve victims only after the agreement is reached, mainly before truth commissions.

\subsubsection{Differential Gender and Ethnic Approaches in the Peace Agreement}

The inclusion of a differential perspective to gender and ethnic minorities is considered as one of the major victories for human rights advocates in the Colombian peace process. The Agreement invokes the incorporation of a differential approach as an expression of the right to equality and nondiscrimination enshrined by international law. ${ }^{332}$

Regarding gender, the preceding legislative and jurisprudential developments derived from international law inspired women and other gender-related groups to ask for their participation and inclusion during the negotiation process. In addition, the UN representatives explicitly called for all the Agreement to incorporate a gender approach and to ensure women participation. ${ }^{333}$ In this way, in September 2014 the parties set up a Gender Sub-commission whose purpose was to "provide recommendations to the Table in order to enable an appropriate

330 Government of Colombia and FArc, 'Final Agreement to End the Armed Conflict and Build a Stable and Lasting Peace,' 8.

331 Government of Colombia and FARC, 126-28.

332 Government of Colombia and FARC, 'Final Agreement to End the Armed Conflict and Build a Stable and Lasting Peace,' 3 .

333 Government of Colombia and FARC, 144. 
gender approach, particularly in relation with women and the LGBTI community." 334

On this topic, the parties went beyond women issues and included a LGBTI-gender related perspective in the Agreement, which is unprecedented in other processes. It was more a consequence of domestic developments on LGBTI issues, ${ }^{335}$ and the acknowledgment of the specific impacts that LGBTI people suffered because of armed conflict. ${ }^{336}$ As such, the parties extended the international law appropriation of gender as related to women to a point in which other gender issues were covered. As Céspedes points out, during the negotiation "women's issues were at the center and LGBT's followed in their path." 337

In general, the Agreement includes equality, gender approach, and ethnic diversity as guiding principles; ${ }^{338}$ calls for the empowerment of women ${ }^{339}$ and the political participation of different identity groups; ${ }^{340}$ highlights the role of women as peacebuilders; ${ }^{341}$ establishes the necessity to ensure a differential approach regarding reincorporated women; ${ }^{342}$ looks for strengthening the administration of justice concerning gender-based violence; ${ }^{343}$ and defines the incorporation of a differential gender and ethnic approach over the system of truth, justice, and reparation..$^{344}$

According to the parties, these measures aim to "create conditions for women, and people with diverse sexual orientation, to access in equal conditions to the benefits of a country without armed conflict." ${ }^{345}$ For the negotiators, "the inclusion of a gender approach in a peace process such as this one

334 Gobierno de Colombia and FARC, 'Joint Communiqué,' 11 September 2014, https://www .ambitojuridico.com/BancoMedios/Documentos\%2oPDF/comunicado11-o9-14.pdf.

335 See, for instance: Corte Constitucional, Sentencia SU-617-2014, C-o71-2015, SU-214-2016.

336 The Colombia's National Centre for Historical Memory elaborated a report on the specific impacts of armed conflict on LG BT people. Centro Nacional de Memoria Histórica, Aniquilar la diferencia, Lesbianas, gays, bisexuales y transgeneristas en el marco del conflicto armado colombiano, 2015, available at: http://www.centrodememoriahistorica.gov .co/descargas/informes2015/aniquilar-la-diferencia/aniquilar-la-diferencia.pdf (accessed on 20 January 2018).

337 Céspedes-Báez, 'Gender Panic and the Failure of a Peace Agreement,' 186.

338 Government of Colombia and FARC, 'Final Agreement to End the Armed Conflict and Build a Stable and Lasting Peace,' 12.

339 Government of Colombia and FARC, 31.

340 Government of Colombia and FARC, 54.

341 Government of Colombia and FARC, 55.

342 Government of Colombia and FARC, 69.

343 Government of Colombia and FARC, 79, 85 .

344 Government of Colombia and FARC, 128.

345 Gobierno de Colombia and FARC, 'Joint Communiqué No. 82,' 24 July 2016, http://es .presidencia.gov.co/noticia/16o724-Comunicado-conjunto-82. 
has no precedents in the world, and sets a milestone in the construction of the agreements already reached and yet to be reached." 346

Regarding ethnic issues, the parties heard a civil society ethnic commission providing recommendations to incorporate a differential ethnic approach into the Peace Agreement. As a result, the Final Agreement included an Ethnic Chapter, ${ }^{347}$ in which it recognizes the serious impacts that armed conflict had on indigenous and Afro-Colombian communities, and the necessity to assume a differential ethnic approach to reach peace. To this effect, the Agreement indicates that it must be interpreted and applied in a way that respects and incorporates the specific needs, concerns, and dynamics of ethnic minorities, according to international and domestic law. On this point, the Agreement invokes the ICESCR, the ICERD, the ILO Convention 169, the Durban Declaration for Action, and the UN Declaration on Indigenous Peoples. ${ }^{348}$

As such, the Agreement established measures as the fundamental right to previous, informed, and free consent regarding the implementation of the peace deal in matters related to ethnic groups; special consideration of ethnic communities' needs on rural development; the restitution of collective ethnic territories and return of displaced ethnic communities; the coordination of the Special Jurisdiction for Peace with the special indigenous jurisdiction; ${ }^{349}$ and a commission to follow-up the observance of the ethnic approach in the implementation of the Agreement. ${ }^{350}$

In all of these matters, the Colombian approach to inclusiveness in its different transitional instruments has consistently been inspired by international law, following legal norms and the discourses and requests of differential groups to ensure international legal standards. As Chapter 3 will analyze, such a normative landscape can be framed by jus post bellum.

This chapter examined how international law has shaped the Colombian transition in different matters and by different ways. At least three reasons explain

346 Gobierno de Colombia and FARC, 'Joint Communiqué.'

347 Government of Colombia and FARC, 'Final Agreement to End the Armed Conflict and Build a Stable and Lasting Peace,' 206-9.

348 Government of Colombia and FARC, 206.

349 According to Article 246 of the Colombian Constitution, indigenous authorities can exercise their own jurisdiction within their territories.

$35^{\circ}$ Government of Colombia and Farc, 'Final Agreement to End the Armed Conflict and Build a Stable and Lasting Peace,' 207-9. 
such an influence of international law in this case. First, the growing development of IHRL, IHL, and ICL has established standards to protect individual rights, even beyond domestic political decisions by states and parties in peace negotiations. As such, the legal developments explored in this chapter showed to the parties in negotiation their inescapable obligation to follow international standards, and it gave legal arguments to actors claiming for their rights and interests to be considered in the negotiations. Second, Colombia has a constitutional system particularly receptive to international law, establishing that duly ratified IHRL and IHL treaties have the same normative level as the Constitution. Thus, the negotiators knew that international law was a parameter to control the constitutionality of the mechanisms designed in the negotiation. For that reason, those mechanisms had to be in conformity with international law. Third, the involvement of international actors in the process and the parties' intention to have an agreement internationally accepted, created a favorable environment for the active role played by international law in the process.

In this way, legal obligations, discourses, and comparative practices created a normative framework in which parties moved to reach their own formulas.

Regarding the legal nature of the agreement, the parties showed a creative use of international law for shielding the accord from domestic political or legal changes. In this case, they framed the peace deal as a special agreement under IHL and through a unilateral declaration by the Colombian State before the UN.

Pursuing a sustainable peace, a broad set of socioeconomic, political, and institutional questions had to be addressed. On this matter, the parties treated the problems related to rural development, political participation, environmental protection, and crops of illicit use under a human rights approach. As such, the parties used an international legal frame of reference, invoking instruments such as the ICCPR and the ICESCR to delineate socioeconomic and political reforms as a matter of rights rather than mere political decisions.

On criminal responsibility, international legal obligations set up a framework with clear conditions to be observed: no amnesty for international crimes, formal prosecution and trials were required, and effective restrictions on liberty had to be imposed as a part of the criminal sanctions. With those elements, the parties created a special system of justice, with formal judges and procedures, trials and sentences, imposing restorative sanctions but including effective restrictions on liberty. Here, the legal obligations enshrined by ICL, IHL, and IHRL regarding amnesties and prosecution of international crimes, together with comparative practices and the discourses of actors such as the Office of the ICC Prosecutor and the Inter-American System of Human Rights, defined a normative bargaining zone within which the negotiators created 
their formula to deal with criminal responsibility for past crimes related to the armed conflict.

Similarly, regarding reparations, the Colombian case shows that it is possible to develop a comprehensive system of reparation even in the context of massive violations of human rights and IHL within an armed conflict. No previous transition from conflict to peace has recognized such a larger number of victims as Colombia did. Although victims of armed conflict represent around $18 \%$ of the total population, the country assumed the comprehensive concept of reparation set by international law, which was defined by reference to international legal norms.

Finally, the participation and inclusion of different groups of people has been assumed not only as a political condition of legitimacy, but as a legal obligation. The parties in negotiation, and several social and institutional actors, have invoked international legal elements to support inclusiveness in transition in Colombia, both in the process of negotiation and in the content of the Agreement, leading to special provisions to address structural factors of discrimination and exclusion.

Therefore, as presented in this chapter, the international legal obligations binding both the Colombian State and the guerilla, the precedents regarding matters as amnesties in other contexts around the world, and the discourses of relevant actors (e.g., guarantor countries, UN agents, the ICC, and other domestic and international institutional and civil society actors) were decisive for the way in which negotiations were conducted and for the very content of the Peace Agreement. In consequence, this chapter showed how practice in Colombia proves the existence of an international normative framework shaping transition from armed conflict to peace. This framework is what the book considers jus post bellum. 